Article

\title{
Transglutaminases and Obesity in Humans: Association of F13A1 to Adipocyte Hypertrophy and Adipose Tissue Immune Response
}

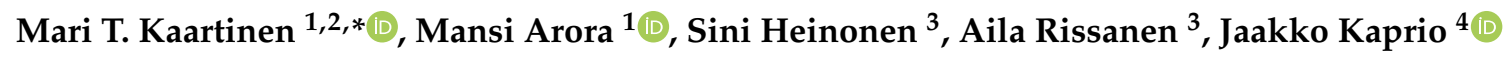 \\ and Kirsi H. Pietiläinen ${ }^{3,5}$ \\ 1 Faculty of Medicine (Experimental Medicine), McGill University, Montreal, QC H3A 0J7, Canada; \\ mansi.arora@mail.mcgill.ca \\ 2 Faculty of Dentistry (Biomedical Sciences), McGill University, Montreal, QC H3A 0J7, Canada \\ 3 Obesity Research Unit, Research Program for Clinical and Molecular Metabolism, Faculty of Medicine, \\ University of Helsinki, 00014 Helsinki, Finland; sini.heinonen@helsinki.fi (S.H.); \\ Aila.Rissanen@medi.inet.fi (A.R.); kirsi.pietilainen@helsinki.fi (K.H.P.) \\ 4 Department of Public Health, University of Helsinki, 00100 Helsinki, Finland; Jaakko.Kaprio@helsinki.fi \\ 5 Abdominal Center, Obesity Center, Endocrinology, University of Helsinki and Helsinki University \\ Central Hospital, 00014 Helsinki, Finland \\ * Correspondence: mari.kaartinen@mcgill.ca; Tel.: +1-514-398-7203 (ext. 089668)
}

Received: 31 August 2020; Accepted: 1 November 2020; Published: 5 November 2020

\begin{abstract}
Transglutaminases TG2 and FXIII-A have recently been linked to adipose tissue biology and obesity, however, human studies for TG family members in adipocytes have not been conducted. In this study, we investigated the association of TGM family members to acquired weight gain in a rare set of monozygotic (MZ) twins discordant for body weight, i.e., heavy-lean twin pairs. We report that $F 13 A 1$ is the only TGM family member showing significantly altered, higher expression in adipose tissue of the heavier twin. Our previous work linked adipocyte $F 13 A 1$ to increased weight, body fat mass, adipocyte size, and pro-inflammatory pathways. Here, we explored further the link of F13A1 to adipocyte size in the MZ twins via a previously conducted TWA study that was further mined for genes that specifically associate to hypertrophic adipocytes. We report that differential expression of $F 13 A 1$ ( $\triangle$ Heavy-Lean) associated with 47 genes which were linked via gene enrichment analysis to immune response, leucocyte and neutrophil activation, as well as cytokine response and signaling. Our work brings further support to the role of $F 13 A 1$ in the human adipose tissue pathology, suggesting a role in the cascade that links hypertrophic adipocytes with inflammation.
\end{abstract}

Keywords: Factor XIII-A; F131A; obesity; weight gain; adipocyte size; inflammation

\section{Introduction}

Transglutaminases (protein-glutamine $\gamma$-glutamyltransferase, TGase, TG, EC 2.3.2.13) are a family of enzymes that catalyze a $\mathrm{Ca}^{2+}$ - and thiol-dependent posttranslational modification of glutamine residues [1-4]. These reactions include acyl transfer reaction with primary amines, glutamine deamination if the second substrate is water, and transamidation, i.e., isopeptide crosslinking, if the second substrate is a lysine of a protein polypeptide chain. The isopeptide formation between glutamine and lysine residues, which is by far the most studied reaction of TGs [1-4], stabilizes proteins and induces formation of protein networks and alterations in substrate protein biochemistry, stiffness, solubility, and cell adhesive features [2,4-7]. TGs also have cell signaling functions that do not require crosslinking activity [8]. 
The TG family consists of nine gene products: TG1-TG7 and Factor XIII-A [1,2,4] (Genes: TGM (human), Tgm (mouse)). Transglutaminases TG2 and FXIII-A have been studied widely in the context of connective tissue hemostasis and differentiation of their resident cell types. While much focus has been on cartilage and bone [9-15], new research also shows their involvement in adipose tissue. White adipose tissue (WAT) is a form of connective tissue capable of thermoregulation and energy storage and it plays a central role in maintenance of balanced energy metabolism [16]. In caloric excess, WAT expands via preadipocyte proliferation (hyperplasia) and by their differentiation to lipid storing adipocytes followed by their growth (hypertrophy) [16]. The current understanding is that adipocyte size is associated with metabolic consequences of obesity in a manner where smaller adipocyte phenotype predicts healthier outcome, and larger adipocytes are linked to insulin resistance and other comorbidities of excess weight $[17,18]$. It is not fully understood why the presence of larger adipocytes presents a worse metabolic outcome in obesity; however, this may at least not link to adipocyte mitochondrial dysfunction [19] but rather on hypertrophic adipocyte-mediated initiation of innate immune reaction [20-22]. In obesity, prolonged inflammation compromises lipid storage and healthy WAT function, which lead to lipid accumulation to non-metabolic tissues $[16,23,24]$. This is linked to the development of insulin resistance and T2D [23].

TG2, which is a ubiquitously expressed TG with a plethora of functions in health and disease, has been linked to adipogenesis and obesity by us [25] and by others [26]. We demonstrated that the absence of TG2 in mouse embryonic fibroblasts increased adipogenesis via several pathways, which included decreased Pref- 1 production, canonical Wnt/ $\beta$-catenin signaling, and increased Akt phosphorylation [25]. The research group of Szondy showed that Tgm2-deficient mice do not gain more weight compared to their controls, however they exhibit increased inflammation of adipose tissue.

A recent genome-wide association study by Pietiläinen's group linked FXIII-A to obesity in weight discordant monozygotic (MZ) twins, and further studies showed that seven small nucleotide polymorphisms (SNPs) in the F13A1 gene are associated with body mass index (BMI) [27]. The work by Kaartinen's group in turn examined the role and mechanisms of action of FXIII-A in 3T3-L1 adipocytes and investigated the metabolic phenotype of high-fat diet-fed F13a1-/- mice. We reported that in cell cultures, the FXIII-A enzyme can act as a switch to modulate insulin signaling from pro-proliferative to pro-differentiating function via regulating plasma fibronectin accumulation into extracellular fibrils [28]. We also showed that F13a1 deficiency in mice alters the adipose tissue cellularity and increases small and large adipocytes but decreases macrophage infiltration and improves insulin sensitivity of obese adipose tissue [29], suggesting that FXIII-A reacts to weight gain and may have an adverse effect on adipose tissue health. In our most recent work, we examined the association of $F 13 A 1$ to human obesity in weight discordant MZ twin pairs, where the association of F13A1 to human obesity was originally discovered [27]. In this clinical study, we reported that the expression of F13A1 is significantly increased in the adipose tissue and adipocyte-enriched fraction of the heavier co-twin, and its differential expression ( $\Delta$ Heavy-Lean) shows a strong, significant linear correlation with increase in weight, fat mass, and adipocyte volume, and a negative correlation with circulating adiponectin [30]. A further transcriptome-wide association study (TWAS) between Heavy-Lean $\triangle F 13 A 1$ and changes in full adipocyte transcriptome between the co-twins identified 182 highly F13A1 correlating transcripts, for which gene enrichment analysis linked cell stress, inflammation, extracellular matrix remodeling, and angiogenesis of the adipose tissue.

The aim of this study was first to investigate the expression of the whole TGM family in acquired excess weight in the MZ twins, and secondly to elucidate details of the links of F13A1 to pathways associated with adipocyte size that may be relevant to metabolism. We report that F13A1 is the only TGM family gene transcript that is significantly linked to acquired weight gain, showing an increase in the heavier twin. F13A1 associated with 47 gene transcripts that also showed a link to large adipocyte size, which mostly represented genes of neutrophil attraction, inflammasome, and secretion of pro-inflammatory cytokines. Our study brings further evidence to the relevance of FXIII-A/F13A1 in adipose tissue health. 


\section{Results}

Our first aim was to examine potential links of TGM family members to excess acquired weight in the 12 weight discordant MZ twins. The significant weight and adipocity discordance of the twins are presented in Table 1 . Differential ( $\Delta$ Heavy-Lean twin) gene expression in adipose tissue and adipocyte-enriched fraction is reflective of cellular changes in the tissue upon its expansion during weight gain. As presented in Figure 1A,B, F13A1 is the only TGM family gene that reacts to excess weight in a significant manner and shows increased expression in both adipose tissue and adipocyte-enriched fraction of the heavier twin [30].

A

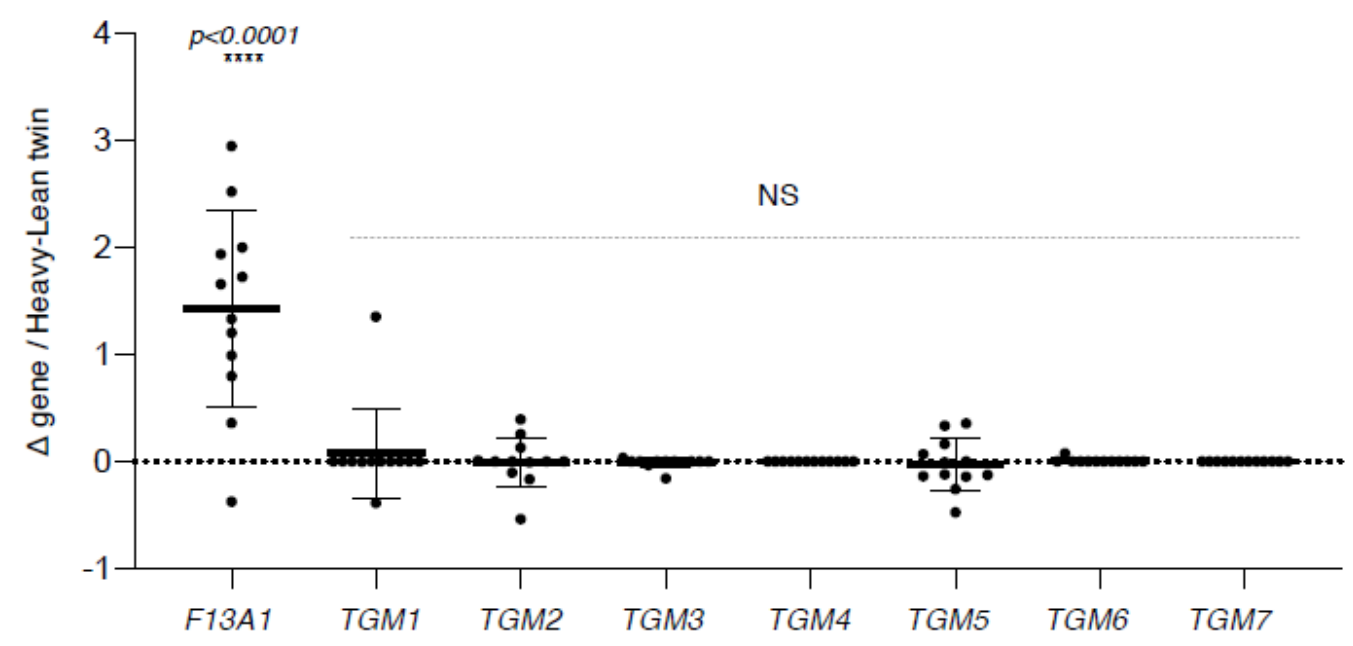

Adipocyte-enriched fraction

B

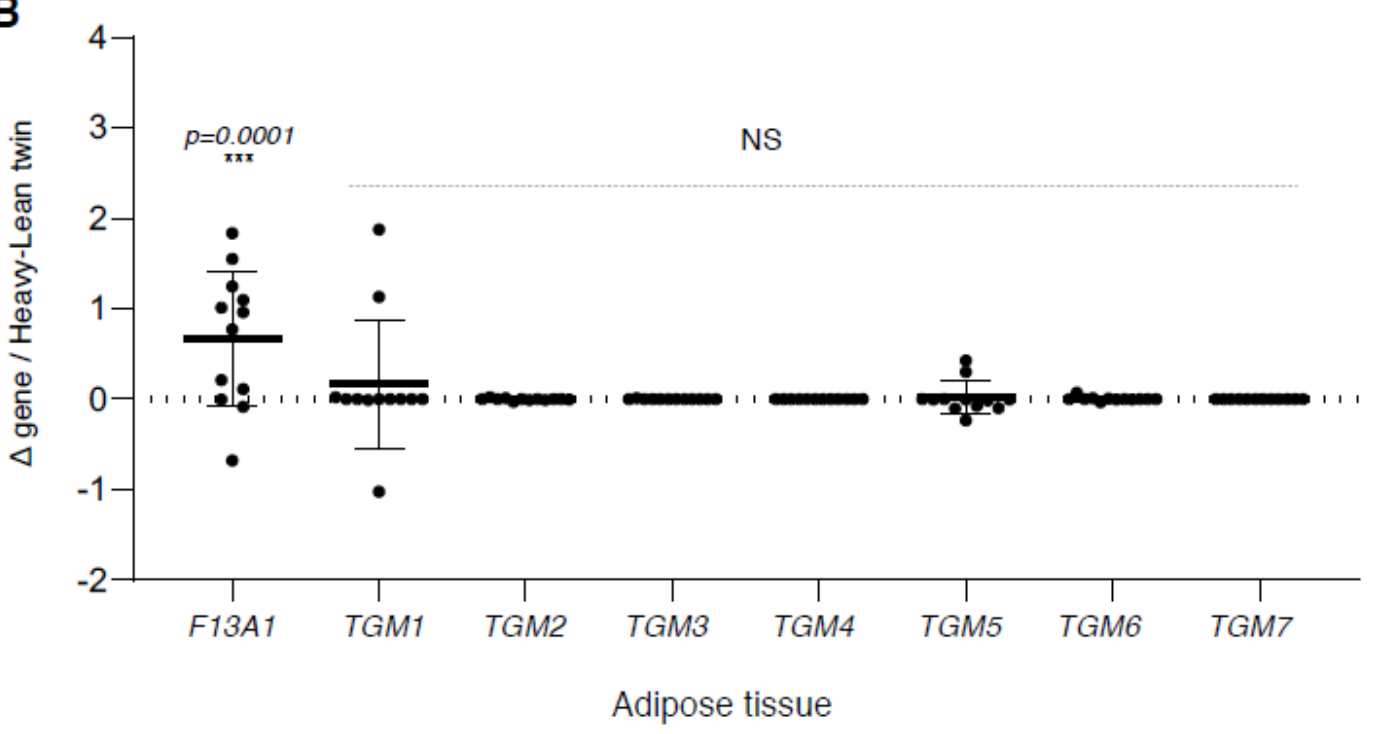

Figure 1. Gene expression of transglutaminase family genes and association of F13A1 mRNA expression in acquired excess weight. Increase in transglutaminase family (TGM) members in excess weight represented by expression difference $(\Delta)$ between heavy and lean monozygotic (MZ) weight discordant twins ( $n=12$ twin pairs). (A) Differential expression in adipocyte-enriched fraction. (B) Differential expression in adipose tissue. Analysis of variance (ANOVA) with Bonferroni post-test shows that F13A1 is the sole TGM family member that reacts to acquired excess weight in both preparations. No significant changes were observed in other TGM family members. NS, not significant. 
Table 1. Clinical characteristics of the twin pairs $(n=12)$ used in this study to obtain transcriptomics data from adipose tissue and adipocyte-enriched fraction. Student's T-test was used to calculate the differences between the twin pairs, and Wilcoxon Signed rank's test to determine the $p$-values.

\begin{tabular}{cccc}
\hline Clinical and Adipocity Parameters & Heavier Co-twin & Leaner Co-twin & $p$-Value \\
\hline Height $(\mathrm{cm})$ & $169.3 \pm 2.89$ & $169.2 \pm 3.0$ & 0.7530 \\
Weight $(\mathrm{kg})$ & $83.8 \pm 4.6$ & $67.0 \pm 4.1$ & 0.0022 \\
BMI $\left(\mathrm{kg} / \mathrm{m}^{2}\right)$ & $29.0 \pm 0.85$ & $23.2 \pm 0.7$ & 0.0022 \\
Body fat $(\%)$ & $41.9 \pm 2.0$ & $32.8 \pm 1.8$ & 0.0029 \\
Body fat $(\mathrm{kg})$ & $34.7 \pm 2.3$ & $22.0 \pm 1.9$ & 0.0022 \\
Fat-free mass $(\mathrm{kg})$ & $46.6 \pm 3.7$ & $42.8 \pm 2.9$ & 0.0029 \\
Subcutaneous fat $\left(\mathrm{dm}^{3}\right)$ & $5762.4 \pm 450.6$ & $3303.6 \pm 275.4$ & 0.0022 \\
Intra-abdominal fat $\left(\mathrm{dm}^{3}\right)$ & $1109.8 \pm 186.4$ & $502.2 \pm 91.2$ & 0.0037 \\
Liver fat $(\%)$ & $2.4 \pm 0.74$ & $0.60 \pm 0.06$ & 0.0076 \\
Triglycerides (mmol/L) & $1.14 \pm 0.07$ & $0.96 \pm 0.11$ & 0.1823 \\
fP-Leptin (pg/mL) & $34,229.0 \pm 5931.3$ & $18,331.8 \pm 4412.6$ & 0.0037 \\
fP-Adiponectin (ng/mL) & $2844.0 \pm 382.1$ & $3520.1 \pm 380.1$ & 0.0186 \\
Adipocyte diameter (mm) & $87.9 \pm 2.82$ & $76.6 \pm 2.77$ & 0.0022 \\
Adipocyte number & $8.8 \mathrm{e}+13 \pm 5.7 \mathrm{e}+12$ & $8.5 \mathrm{e}+13 \pm 8.2 \mathrm{e}+12$ & 0.4328 \\
\hline
\end{tabular}

BMI: body mass index, fP: fasting plasma. Data are presented as mean \pm SEM.

Our previous work linked increase in F13A1 expression to increase in adipocyte size/volume [30]. This, with previous mouse data, suggests that $F 13 A 1$ may be increasingly produced by larger adipocytes or may regulate the cell size. In the same study, we identified 182 F13A1- and weight-associated genes which showed significant $(p<0.05)$ and strong Pearson correlation $(\mathrm{r}>0.7)$ for Heavy-Lean $\triangle F 13 A 1$ [30]. Gene enrichment analysis showed that the 182 genes linked to cell stress, inflammation, tissue remodeling, hemostasis, and angiogenesis [30]. To further examine the link of F13A1 to adipocyte size, we applied the following strategy (Figure 2). First, the pool of 182 genes was further screened for genes that also showed correlation to Heavy-Lean $\triangle$ Adipocyte Diameter in the $12 \mathrm{MZ}$ twin pairs. This resulted in a total of 283 genes from which 42 were found as shared with the original 182 gene set. Second, we screened the set for adipocyte size correlating (positive and negative) genes that were identified from $15 \mathrm{MZ}$ twins, some of which were shared with this study [17]. This resulted in no additional genes (Supplemental Tables S1 and S2). Third, we screened 14 reported 'large adipocyte genes' from a study where adipocytes, isolated from human SAT, were separated via $70 \mu \mathrm{m}$ mesh into small $(57.8 \pm 0.23 \mu \mathrm{m})$ and large $(95 \pm 0.38 \mu \mathrm{m})$ adipocytes, followed by mRNA expression analysis and identification of genes that were expressed more than four-fold in large adipocytes versus small ones [18,31] (Supplemental Table S3). From this set, three additional F13A1- and weight-correlated genes were identified (SELE, IL8, and LPCAT1). Fourth, we searched the literature for genes that have been published to regulate adipocyte size. A literature search ('adipocyte size' and 'regulation' and 'gene') resulted in 835 papers, from which 17 reported on genes with strong links to regulation of adipocyte size (associations were not included) (Supplemental Table S4). Only one out of these genes was found in the set of 182 genes (REPIN1). Thus, a total of 383 'adipocyte size' genes were screened, which resulted in a final set of 47 gene transcripts that showed significant correlation to $\triangle F 13 A 1$ and were differentially expressed in the Heavy vs. Lean twin. Classical regulators of adipogenesis and lipid storage, PPARG, CEBPA, CEBPB, and PLIN1, did not show correlation. The set of 47 genes are listed in Table 2. From this set, 12 genes showed strong negative correlation with $\triangle$ Weight-, $\triangle F 13 A 1-$, and $\Delta$ Adipocyte Diameter. The remaining 35 genes were positive correlators. 


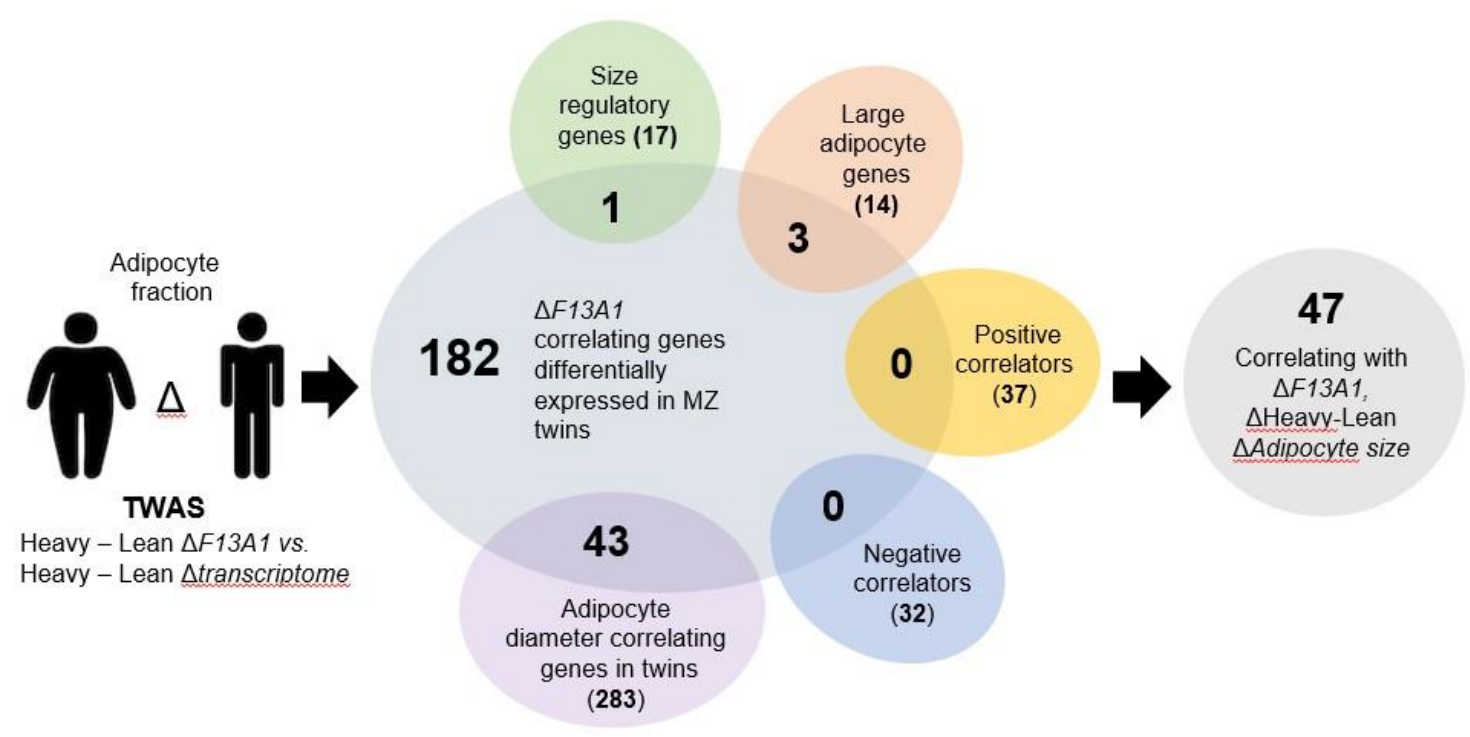

Figure 2. Transcriptome-wide association study (TWAS) strategy to investigate the association of F13A1 with acquired excess weight and adipocyte size in weight-discordant monozygotic twins. To examine what weight gain and adipocyte size-associated pathways $F 13 A 1$ is linked to, we performed a transcriptome-wide association study (TWAS) of differentially expressed and correlated genes (Heavy-Lean $\triangle F 13 A 1$ vs. Heavy-Lean $\Delta$ transcriptome). The initial screen identified 182 genes whose differential expression showed significant linear correlation with F13A1 ( $\mathrm{r}^{2}>0.5$ and $\left.p<0.05\right)$ and significant differential expression between the Heavy and Lean co-twins $(p<0.05)$ [32]. This set was screened for previously published adipocyte size correlating (positive and negative) genes in the MZ twins, some of which were shared with this study. This resulted in no additional genes. The set was then screened for 14 reported 'large adipocyte genes' and 17 genes from the literature that have been published to regulate adipocyte size (PubMed search ('adipocyte size' and 'regulation' and 'gene')). All screened genes are listed in Supplemental Tables S1-S4. The resulting final set of 47 genes that correlated with $F 13 A 1$, adipocyte diameter, and were differentially expressed in the co-twin pairs are listed in Table 2.

Table 2. List of 47 genes showing strong and significant correlation Heavy-Lean $\triangle F 13 A 1, \Delta$ Adipocyte Diameter, and significantly altered expression between the $12 \mathrm{MZ}$ co-twins. Genes are ranked based on smallest $p$-value.

\begin{tabular}{|c|c|c|c|c|}
\hline \multicolumn{5}{|c|}{ Positive Correlation } \\
\hline Gene Symbol & Gene ID & Gene Name & Pearson (r) & $p$-Value \\
\hline CPVL & ENSG00000106066 & Carboxypeptidase, vitellogenic-like & 0.946 & 0.00000097 \\
\hline PYCARD & ENSG00000103490 & PYD and CARD domain containing & 0.941 & 0.00000167 \\
\hline CTSS & ENSG00000163131 & Cathepsin S & 0.902 & 0.00002544 \\
\hline ITGAM & ENSG00000169896 & Integrin subunit alpha M & 0.885 & 0.00005774 \\
\hline DCLK1 & ENSG00000133083 & Doublecortin-like kinase 1 & 0.867 & 0.00012405 \\
\hline$C Y B B$ & ENSG00000165168 & Cytochrome b- 245 beta chain & 0.856 & 0.00018955 \\
\hline SRGN & ENSG00000122862 & Serglycin & 0.842 & 0.0003081 \\
\hline TM4SF1 & ENSG00000169908 & Transmembrane $4 \mathrm{~L}$ six family member 18 & 0.834 & 0.00039092 \\
\hline$P D E 4 B$ & ENSG00000184588 & Phosphodiesterase 4B & 0.834 & 0.00039317 \\
\hline TFPI & ENSG00000003436 & Tissue factor pathway inhibitor & 0.83 & 0.00044582 \\
\hline ANXA4 & ENSG00000196975 & Annexin A4 & 0.827 & 0.00049387 \\
\hline IL8 & ENSG00000169429 & Interleukin 8 & 0.806 & 0.00087858 \\
\hline$V C A N$ & ENSG00000038427 & Versican & 0.806 & 0.00088439 \\
\hline$B C L 2 A 1$ & ENSG00000140379 & BCL2-related protein A1 & 0.802 & 0.00097386 \\
\hline LCP1 & ENSG00000136167 & Lymphocyte cytosolic protein 1/Plastin-2 & 0.802 & 0.00097956 \\
\hline RECK & ENSG00000122707 & $\begin{array}{l}\text { Reversion inducing cysteine-rich protein with } \\
\text { kazal motifs }\end{array}$ & 0.799 & 0.00105162 \\
\hline$A B I 3 B P$ & ENSG00000154175 & ABI family member 3 binding protein & 0.795 & 0.00115971 \\
\hline$I L 1 B$ & ENSG00000125538 & Interleukin 1 beta & 0.786 & 0.00145102 \\
\hline
\end{tabular}


Table 2. Cont.

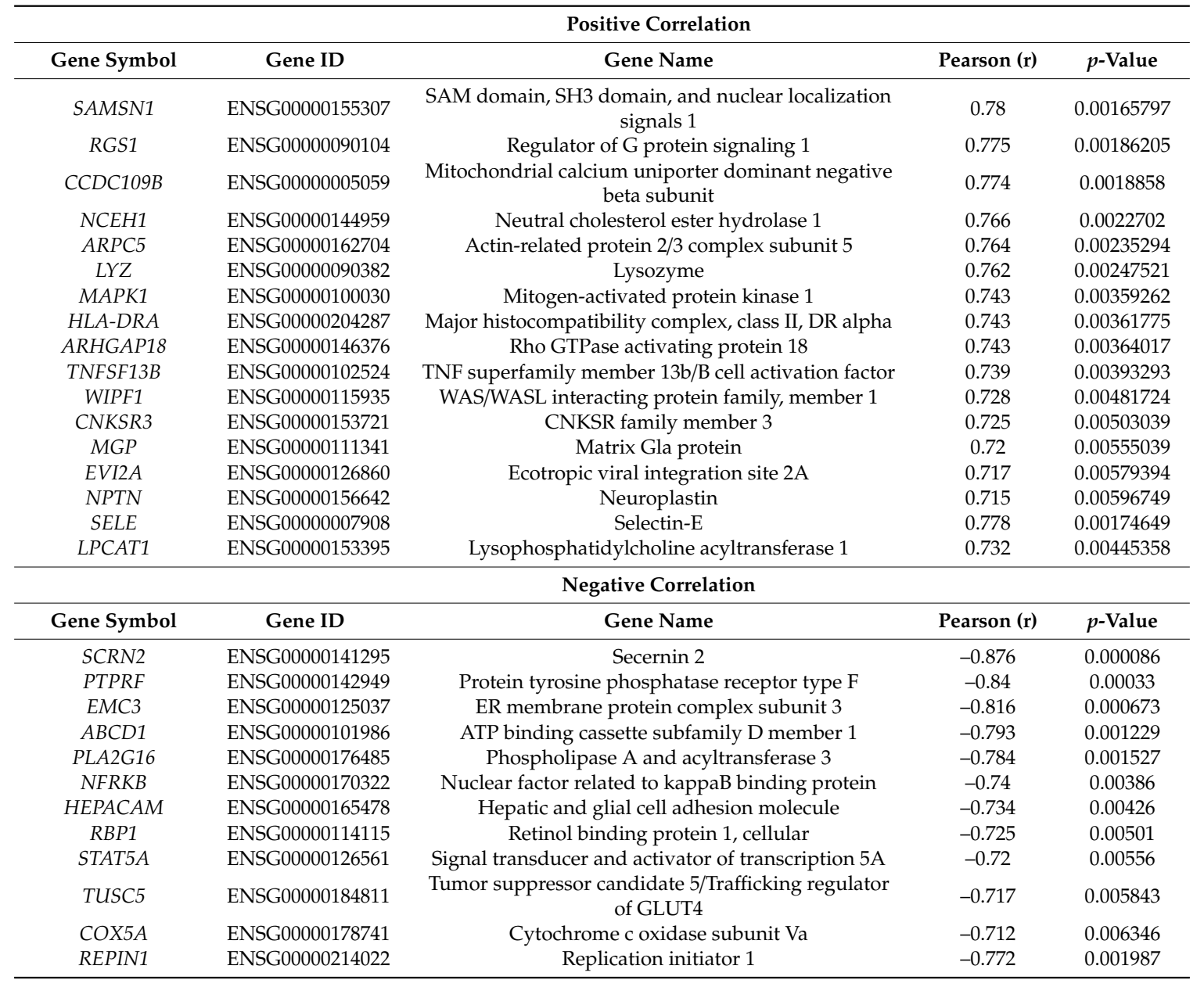

Gene enrichment analysis for the 47 genes, with GOnet and Panther gene ontology tools, resulted in a total of 61 GOterms for Biological Process (BP), 13 Cellular Component (CC), and no terms for Molecular Functions. Figure 3 shows a selection [28] of the most significant, over-represented Biological Process GOterms and all 13 Cellular Component terms. The full list of GOterms is listed in Supplemental Tables S5 and S6. Further cluster analysis (Figure 4) for the GOterms using the GOnet tool revealed three clear functional clusters related to immune response, inflammation, and cytokine response and signaling. A detailed examination of each of the clusters revealed central GOterms, suggesting inflammatory response to external factors via neutrophil and leucocyte activation as well as cytokine secretion (Figures 5-7). Each of the Biological Process and Cellular Component terms and some relevant genes are discussed below in more detail. 


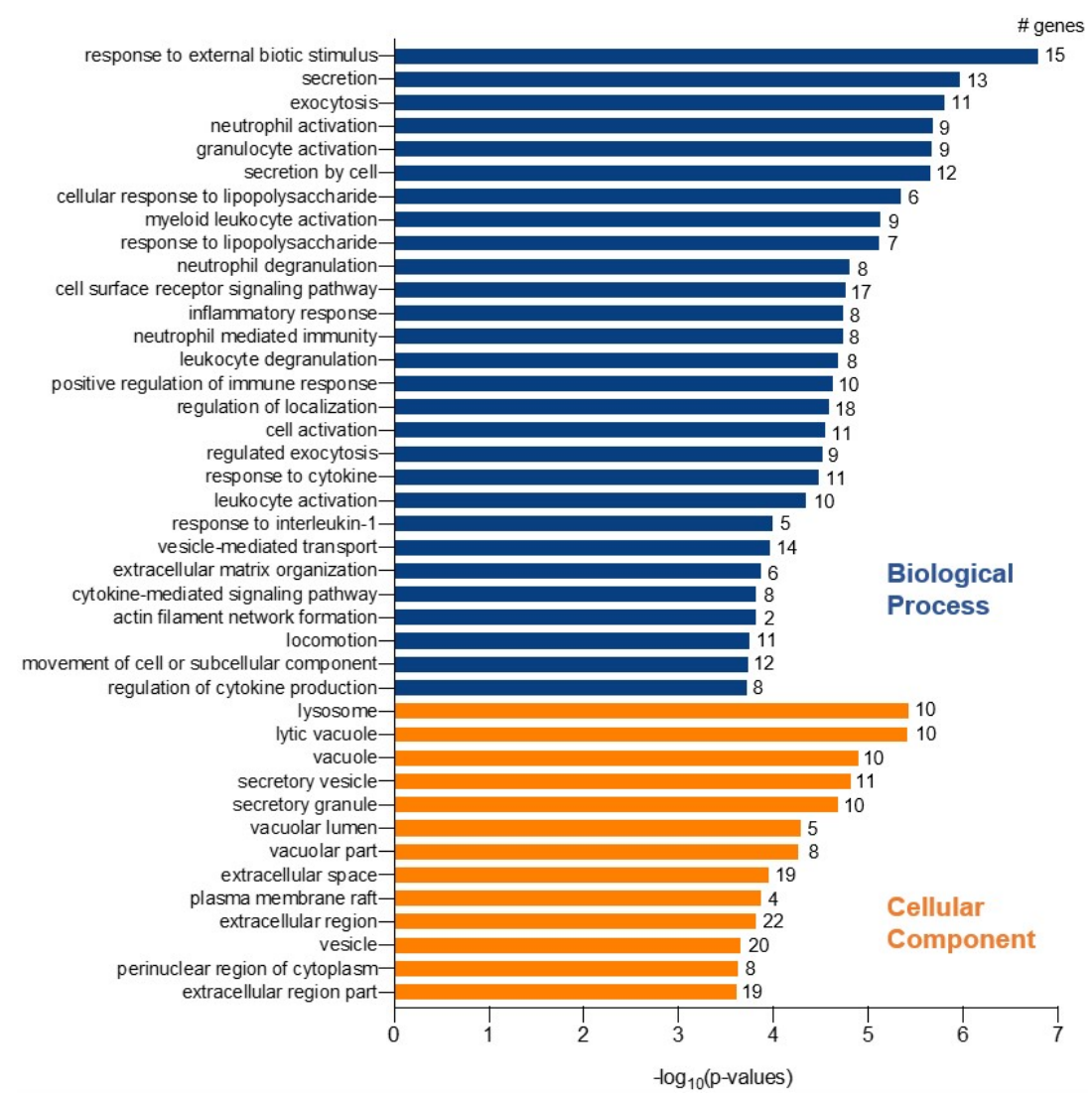

Figure 3. Gene enrichment analysis. Selected over-represented GOterms among the 47 genes whose differential expression correlated with $F 13 A 1$, adipocyte diameter, and showed significantly altered expression between heavy and lean co-twins. Gene ontology analysis was done using GOnet and confirmed with Panther. A total of 61 GOterms were found for Biological Process, and 28 highly relevant are represented here. All 13 Cellular Component terms are shown. No terms for Molecular Functions arose in the search. Significance of the terms is represented as - $\log _{10}$ ( $p$-value) and number of genes in each GOterm is indicated with the bar. Full set of the GOterms with $p$-values, as well as false discovery rate adjusted $p$-values and list of genes can be found in Supplemental Tables S5 and S6.

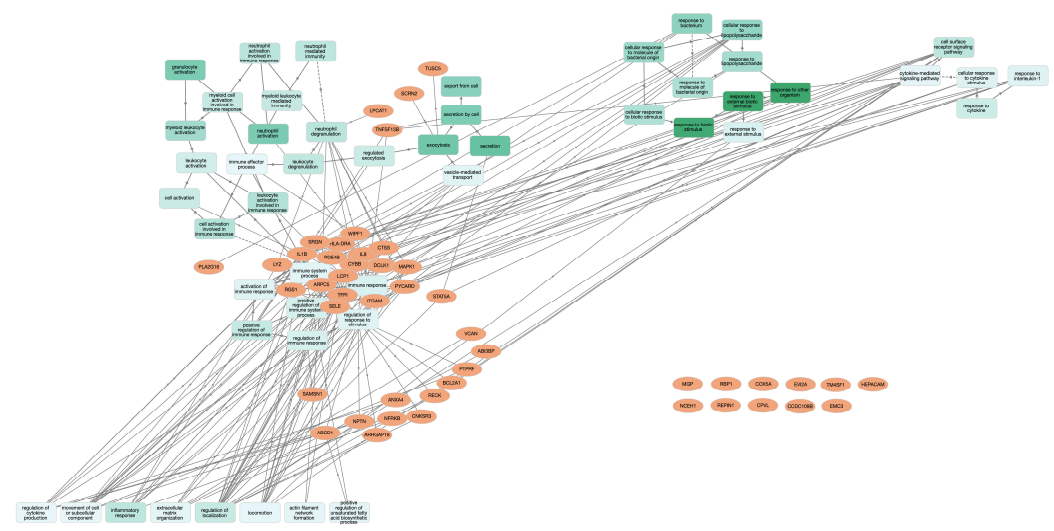

Figure 4. Network of gene ontology terms from 47 genes correlating with F13A1, adipocyte size, and acquired excess weight links $F 13 A 1$ to inflammatory status of adipose tissue. Gene ontology term, gene clustering, and mapping analysis was performed using GOnet web-application (http: //tools.dice-database.org/GOnet/). Analysis is presented as modified Euler layout which reveals three clear functional clusters linked to inflammatory response. The darker color of the GOterm node represents higher significance. The full set of values and GOterms are presented in Supplemental Tables S5 and S6. 


\section{Discussion}

Adipose tissue expansion through hypertrophy, where large adipocytes predominate in the expanding tissue, correlates with adipose tissue low-grade systemic inflammation and worse metabolic consequences of obesity [33-36]. The mechanisms and pathways that precede and follow the hypertrophic expansion and inflammation are numerous. Accumulating data points to sequela that involves free fatty acid (FFA)-mediated initiation of adipocyte hypertrophy, which is followed by initiation of innate immune response by the hypertrophic adipocytes [34]. Previous studies have linked two TGM family members, TGM2 and F13A1, to adipose tissue biology and inflammation $[25,26,28-30,37-39]$. In this study, we have investigated the differential expression of the whole TGM family in adipose tissue of MZ twins that are discordant in weight (Heavy-Lean twin pairs). The $\mathrm{MZ}$ twins are a unique model of acquired weight gain where background involving genetic, age, sex, and early environmental influences can be controlled. The twins' adipocity parameters and metabolism are well characterized and include adipocyte morphology, mitochondrial, fibronolytic and coagulatory, and inflammatory status [40-47]. We report that F13A1 is the sole TGM family member that shows significantly altered, and in this case increased, expression in the heavier twin. Despite robust data from mouse studies linking TG2 to adipose tissue function in obesity $[25,26]$, TGM2 showed no altered expression between the Heavy-Lean co-twins. Further studies in larger cohorts of more severely obese individuals could shed more light into the role of TG2 in human adipose tissue pathology.

The presence of large versus small adipocytes in adipose tissue in obesity has been associated with worse metabolic outcome [18]. Our previous work linked increase in F13A1 in adipose tissue to increased adipocyte size [30]. The aim of this current study was to further examine through which pathways $F 13 A 1$ associates to large adipocytes. This was done by screening the pool of the previously identified 182 F13A1- and weight-correlating genes [30] in the adipocyte-enriched fraction for: (1) genes that have been reported to associate positively or negatively to adipocyte size [17], and (2) genes that are expressed significantly more in larger adipocytes or demonstrated in the literature to regulate adipocyte size $[18,31]$. Here, we demonstrate tight association of $F 13 A 1$ to 47 'adipocyte size' genes that via gene enrichment analysis linked to Biological Processes involving response to external stimulus, secretion, exocytosis, vesicle-mediated transport, cell surface receptor signaling, neutrophil activation, and response to interleukin 1. The GOterms for Cellular Components suggested association of F13A1 in lysosome, secretory vesicles, plasma membrane rafts, and extracellular space. Network and cluster analysis of the GOterms link these to immune response/inflammation and cytokine response (Figure 4), which jointly suggest that $F 13 A 1$ may be involved in pro-inflammatory response from large adipocytes. In our previous study, we discussed several genes that are also among the current 47 genes and they were associated with adipocyte oxidative stress, extracellular matrix (ECM) organization and remodeling, angiogenesis, and macrophages [30]. Associations to all the above processes suggests that F13A1 may be involved throughout in molecular events of the tissue expansion.

The adipocyte-enriched fraction used in this study was prepared from SAT biopsies by a method involving collagenase digestion followed by collecting of the released, buoyant adipocytes. This method is considered to separate adipocytes from the stromal vascular fraction that contain pre-adipocytes, mesenchymal stem cells, endothelial and vascular smooth muscle cells, and immune cells [48], however, other cell types do co-purify and contribute to the transcripts observed. Thus, the preparation enriches adipocytes, but is not void of other cell types. It has become apparent that pure adipocyte preparations require flow cytometry sorting and is more difficult than previously considered [49]. The other cell types have likely co-purified and may include macrophages whose marker ITGAM (Integrin $\alpha \mathrm{M} ; \mathrm{CD} 11 \mathrm{~b}$ ) is present also in this final set of 47 genes. The preparation also likely includes endothelial cells, which as suggested by the expression of genes like SELE (Selectin E) [30], is a product of cytokine-stimulated endothelial cells and mediates endothelial cell adhesion to leucocytes [50]. Macrophages and endothelial cells also both produce FXIII-A enzyme [3,51-59]. Our major future aims include detailing the cell types that are responsible for $F 13 A 1 / F 13 a 1$ production at different phases 
of adipose tissue expansion, which is critical to understanding where in the inflammatory sequela F13A1/F13a1 may be involved.
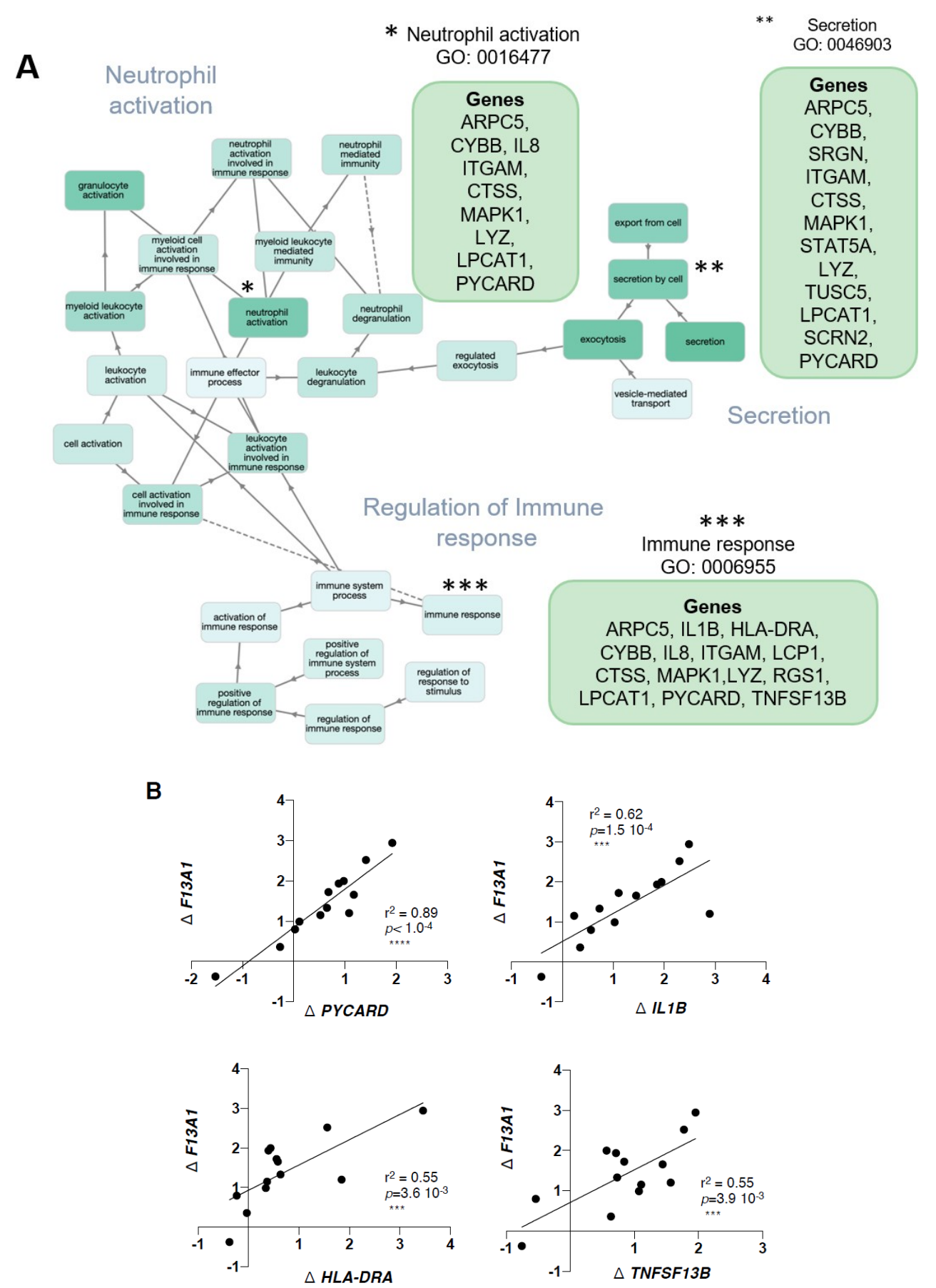

Figure 5. F13A1 expression in adipocyte-enriched fraction associates with neutrophil activation and early immune response. (A) Map of GOterm nodes representing Biological Processes involved in immune response. Node clusters for neutrophil activation, secretion, and regulation of immune response are evident. Gene lists for representative nodes are shown. (B) Linear correlation of $\triangle F 13 A 1$ (Heavy-Lean twin) with differential expression $\triangle$ gene (Heavy-Lean twin) of selected genes from GOterms. F13A1 levels increase in adipocyte-enriched fraction together with PYCARD (an inflammasome and caspase-1 activator), IL1B (interleukin 1b) (early pro-inflammatory cytokine), and HLA-DRA (HLA class II histocompatibility antigen presenting factor, and TNFSF13B (TNF Superfamily Member $13 \mathrm{~b}$ and B-cell activating factor)). 
Of the 47 gene transcripts that correlate with weight, $F 13 A 1$, and adipocyte size, we have discussed four in our previous study (CYBB, CTSS, ITMG, and VCAN) [30]. Below, we will focus mostly on the new ones identified here. The most numerous GOterms for Biological Processes were associated with neutrophil and leucocyte activation (Figure 5). One of the highest $F 13 A 1$ correlating genes in this set was PYCARD $\left(\mathrm{r}^{2}=0.89\right)$ (Figure $\left.5 \mathrm{~B}\right)$, which encodes for ASC (apoptosis-associated speck-like protein containing a CARD). PYCARD/ASC is made up by macrophages, where it activates inflammasome via acting as an adaptor protein between Nlrp3 and caspase-1 [60]. Caspase-1 is critical for proteolytic activation and secretion of pro-inflammatory cytokines IL1 $\beta$ and IL-18 [61,62]. The presence of FFAs in adipose tissue can induce activation of inflammasome [61] and its essential role in metabolic disturbances has become clear $[61,63,64]$. A very recent work demonstrated that the absence of these three critical inflammasome components, Nlrp3, ASC, and caspase-1, in mice protects mice from HFD-induced obesity, insulin resistance, and adipocyte hypertrophy [64]. The Heavy-Lean increase in $\triangle I L 1 B$ also shows strong linear correlation to $\triangle F 13 A 1\left(\mathrm{r}^{2}=0.62\right)$ (Figure $\left.5 \mathrm{~B}\right)$. IL1 $\beta$ is one of the major pro-inflammatory cytokines whose role in metabolic dysfunction is well documented [65].

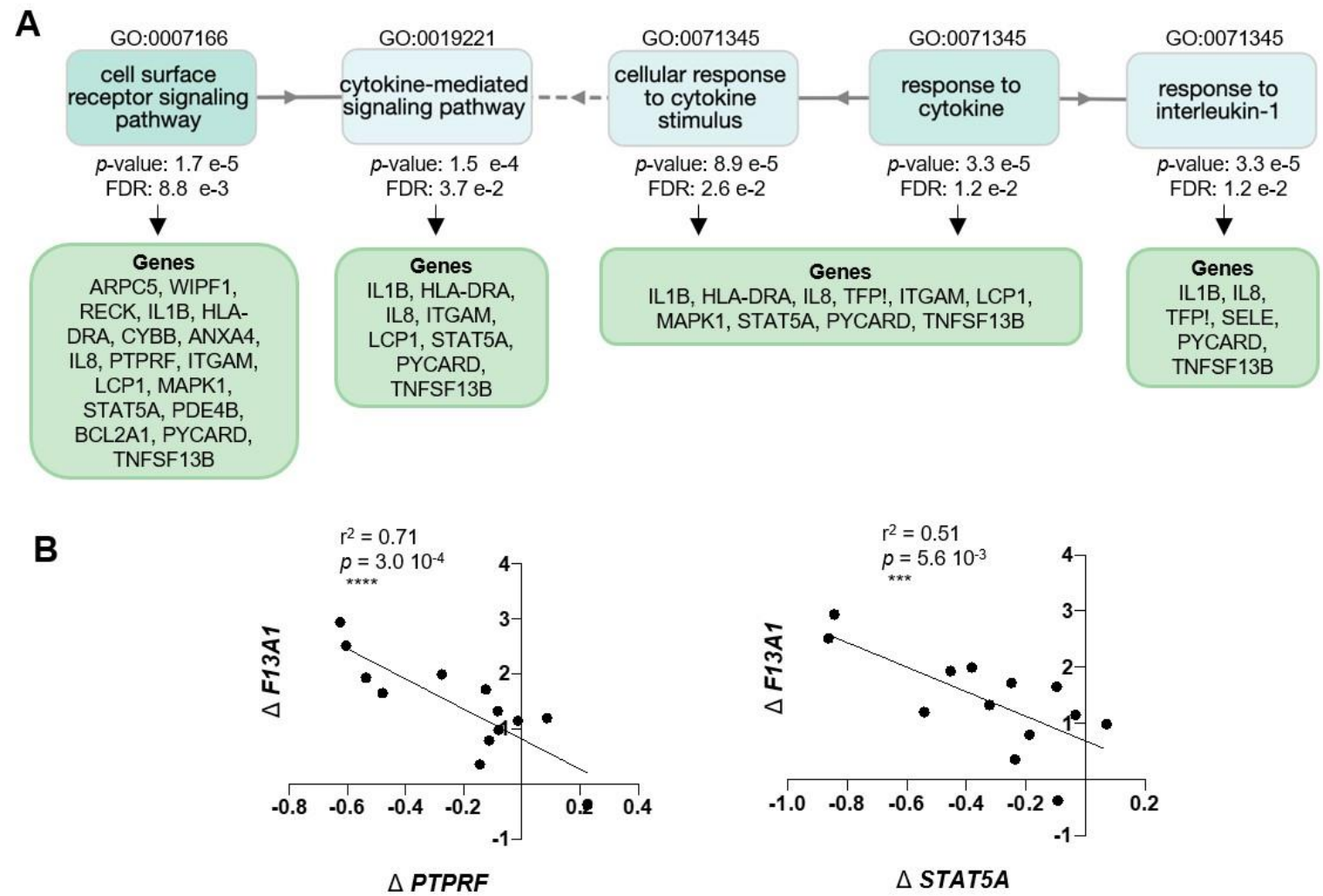

Figure 6. F13A1 expression in adipocyte-enriched fraction associates with cytokine-mediated signaling pathways. (A) Map of GOterm nodes representing Biological Processes involved in responding to external stimuli. Gene lists for representative nodes are shown. (B) Linear correlation of $\triangle F 13 A 1$ (Heavy-Lean twin) with differential expression $\Delta$ gene (Heavy-Lean twin) of selected genes from GOterms. F13A1 levels in adipocyte-enriched fraction negatively correlate with PTPRF, a positive inhibitor of insulin signaling, and to STAT5A, a promoter of adipocyte differentiation. 


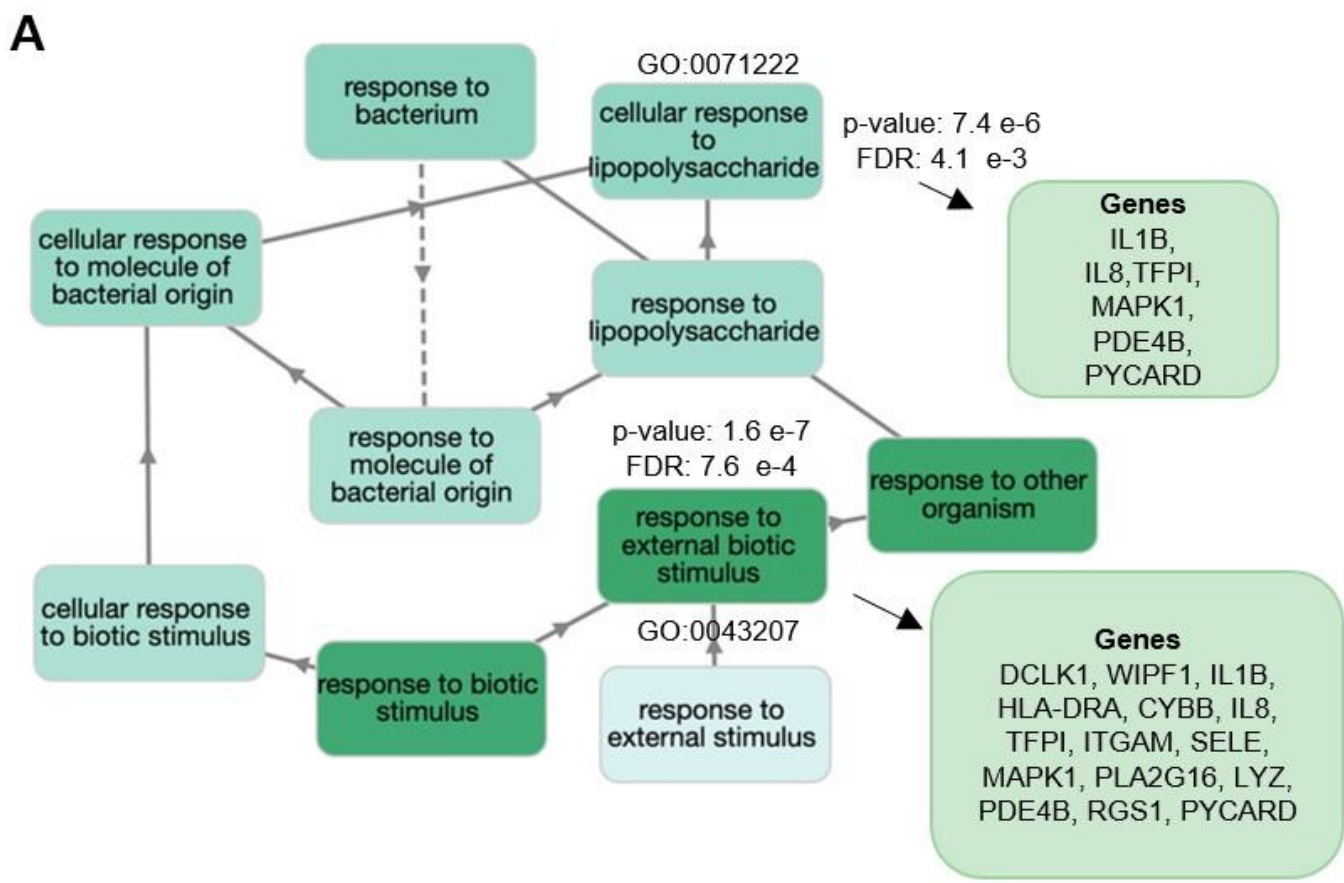

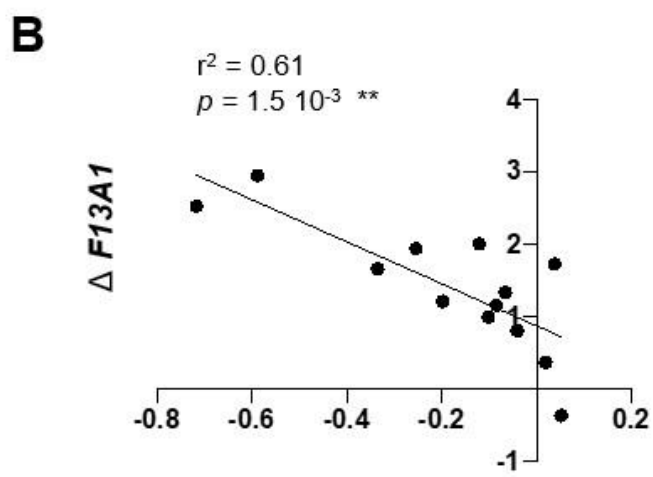

$\triangle P L A 2 G 16$

Phospholipase A2

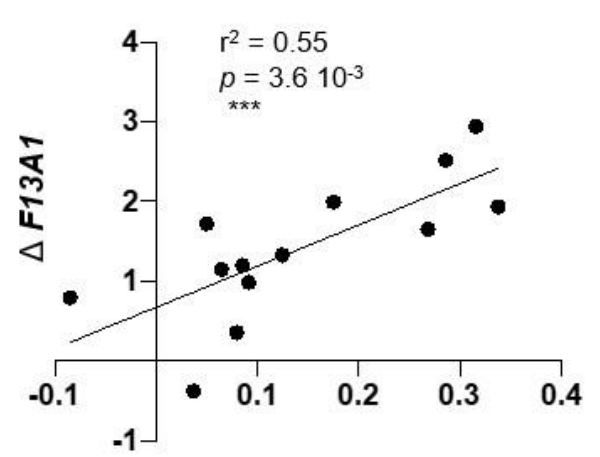

$\triangle M A P K 1$

Figure 7. F13A1 expression in adipocyte-enriched fraction associates with immune response to external factors and stimulus. (A) Map of GOterm nodes representing Biological Processes involved in responding to external stimuli. Gene lists for representative nodes are shown. (B) Linear correlation of $\triangle F 13 A 1$ (Heavy-Lean twin) with differential expression $\Delta$ gene (Heavy-Lean twin) of selected genes from GOterms. F13A1 levels in adipocyte-enriched fraction correlate negatively with PLA2G16 (phospholipase A2), a lipolytic enzyme, and positively with expression of MAPK1.

Neutrophils are the first responders of acute inflammatory reaction and are the first cells to be recruited to the site of inflammation [66-69]. They are the most populous but short-lived cell type in early inflammation and are capable of producing large quantities of cytokines and chemokines, including TNF- $\alpha$, IL- $1 \beta$, and IL- 8 , which can initiate the second wave of immune cells, such as infiltration of macrophages and lymphocytes [66-69]. The role of neutrophils in adipose tissue inflammation has also become apparent [33,70,71]. The links of F13A1 to both neutrophil and leucocyte activation (Figure 5) supports a role in early inflammation as well as perpetuation of the pro-inflammatory milieu. The genes contributing to GOterms that link F13A1 to neutrophil activation are, among others, CYBB (NADP oxidase) (Nox2), which is made by neutrophils and macrophages and responsible for generation of reactive oxygen species and oxidative stress, which in turn can activate neutrophils and neutrophil extracellular trap formation [72]. In adipose tissue, CYBB/Nox2 contributes to adipose tissue inflammation and development of insulin resistance [73]. 
The presence of TNFSF13B (TNF Superfamily Member 13b) (also known as BAFF) in the set of 47 weight and F13A1 correlating genes also supports neutrophil links (Figure 5B). TNFSF13B/BAFF is a neutrophil-derived cytokine that supports B lymphocyte survival. B lymphocytes can tune adipose tissue inflammation via secreting cytokines and immunoglobulins, and they contribute to metabolic failure of adipose tissue $[63,74,75]$. BAFF is also produced by adipocytes [76]. The role of F13A1 in inflammation in many tissues is supported by vast literature and it is expressed by macrophages and dendritic cells [51,52,77-82]. The mechanisms by which FXIII-A contributes to inflammation involve its fibrin-stabilizing function [83,84] and monocyte/macrophage adhesion [79,85]. It may also crosslink other substrates such as plasma fibronectin [28,29]. It is not known if $F 13 A 1$ is produced by neutrophils themselves.

Cluster analysis of GOterms also revealed that F13A1 links to cytokine-mediated signaling pathways (Figure 6). Here, we demonstrate two indicators that show that $F 13 A 1$ is also negatively associated with important insulin modifiers, which is apparent from its negative correlation to $P T P R F$ and STAT5A. The $\triangle F 13 A 1 / \triangle P T P R F$ linear regression graph in Figure $6 \mathrm{~B}$ shows that the high increase in F13A1 correlated with a smaller increase in PTPRF. PTPRF encodes for Protein Tyrosine Phosphatase Receptor Type F (also known as LAR), which inhibits the insulin receptor activation [86,87]. PTPRF/LAR knockdown in adipocytes increases adipogenesis [88] and in mice, disturbances in glucose homeostasis [89]. This data interestingly links high F13A1 to promotion to insulin signaling, which we demonstrated in 3T3-L1 adipocytes [28]; however, in mice, the F13A1 absence improves insulin sensitivity [29]. Also, negative association to STAT5A (Figure 6B) (Signal Transducer and Activator of Transcription 5A), a known promoter of adipogenesis and adipocyte differentiation, supports our previous cell culture results, where FXIII-A was required for pre-adipocyte proliferation but was rapidly downregulated during adipogenesis [28]. The link to large adipocytes suggests that it is also made later during hypertrophy, however this could also mean that large adipocytes induce F13A1 in other adipose tissue cells. Interestingly, recent advances in understanding the phenotypes and functionality of large, hypertrophic adipocytes in adipose tissue in obesity has shown that they likely function as antigen-presenting cells to active innate immunity/immune cells via MHCII and play an important role in the initiation of adipose tissue inflammation [20,90]. Mature adipocytes have also been demonstrated to express leucocyte chemo-attractants that via direct adipocyte-leucocyte interaction stimulate T-cell proliferation [91]. The correlation of F13A1 to HLA-DRA (Figure 5B), an HLA class II histocompatibility complex component, found on the surface of antigen presenting cells, could suggest a link to large adipocytes specialized to initiation of inflammation.

The stimuli initiating F13A1 production, cell types producing it, and cellular location/externalization and activation in adipose tissue are major questions arising from this study. Here, the increase of $F 13 A 1$ is linked to GOterms for cellular response to external stimuli and response to lipopolysaccharide (LPS), supporting the idea that F13A1 could be induced by those factors that initiate the inflammatory reaction. The stimuli that can initiate adipose tissue inflammation are complex and numerous $[33,34]$ and include fibrosis and alterations in extracellular matrix components and stiffness [83,92-96], apoptosis and necrosis of hypertrophic adipocytes [97], hypoxia from defective angiogenesis [24,98], free fatty acids (lipotoxicity) [21], and exogenous, as well as gut microbiota-derived LPS [36]. The GOterms for this cluster of Biological Processes are presented in Figure 7, and there are two genes of particular interest PLA2G16 and MAPK1.PLA2G16 - phospholipase 2A-a lipolytic enzyme made in hypertrophic adipocytes that produces FFAs and induces hyperlipidemia $[99,100]$. Coregulation between PLA2G16 and F13A1 could thus imply a link to FFAs. Positive association with MAPK1 (Figure 6B) is also worthy of mention as we demonstrated that in osteoblasts, extracellular collagen type I, also produced by adipocytes, is a major regulator of FXIII-A expression and externalization [15]. MAPK1 is also needed for lipolysis in rat and mouse adipocytes [101,102].

Our original screen contained a set of regulatory genes demonstrated to modulate adipocyte size. From the final set of genes, 46 of the 47 were large adipocyte-associated genes and only one, REPIN1, was a gene that has been demonstrated to regulate adipocyte size and whole-body insulin 
sensitivity [103]. The association between F13A1 and REPIN1 is negative $\left(\mathrm{r}=-0.77 ; \mathrm{r}^{2}=0.70 ; p=0.0002\right)$, i.e., higher $\triangle R E P I N 1$ levels link to lower $\triangle F 13 A 1$. This and the positive association of $\triangle F 13 A 1$ to $\triangle$ Adipocyte Diameter and $\triangle$ Adipocyte Volume [30] strongly suggests that majority of $F 13 A 1$ is a result of adipocyte hypertrophy-induced events in weight gain, rather than it being a gene that influences the adipocyte size. Detailed weight gain studies in mice can address when F13a1 transcription and protein production is initiated, when and how it is activated during adipose tissue expansion, and what are the consequences of its absence or its overexpression to adipocytes and adipose tissue inflammatory cells and processes. These studies are ongoing in our laboratory.

In conclusion, our study brings further evidence to the involvement of F13A1 in the pathological response of adipose tissue to expansion in weight gain in humans. The concepts revealed in our study suggest novel pathways linked to $F 13 A 1$ and inflammation providing many new hypotheses to be explored that will hopefully show if FXIII-A could be a target to control inflammation of adipose tissue.

\section{Materials and Methods}

\subsection{Weight-Discordant MZ Twins}

This study involved 12 rare, healthy MZ twin pairs discordant for weight (intra-pair difference in acquired excess weight $\Delta$ BMI (body mass index) $\geq 3 \mathrm{~kg} / \mathrm{m}^{2}$ (males $n=2$, females $n=10$, aged $27,7 \pm 1.4$ years)) which were identified from two population-based twin cohorts, FinnTwin16 ( $n=2839$ pairs) and FinnTwin12 $(n=2578$ pairs) [104]. A detailed description of the twin material has been published previously $[45,105]$. The twins were healthy and were not on any regular medication, excluding contraceptives. Table 1 describes the clinical characteristics of the 12 twin pairs regarding weight and adipocity. This data table has been also presented in Reference [30]. All participants have given a written informed consent. The study design was approved by the Ethical Committee of the Helsinki University Central Hospital.

\subsection{Adipose Tissue Biopsies, Adipocyte and Tissue Preparations, and RNA Extraction}

Abdominal subcutaneous adipose tissue (SAT) biopsies were obtained surgically under the umbilicus under local anesthesia. Specimens were flash frozen in $-80{ }^{\circ} \mathrm{C}$ liquid nitrogen. Adipocyte-enriched fraction was prepared by a previously reported protocol which involved adipose tissue digestion in $2 \%$ collagenase dissolved in DMEM/F-12 with supplements and $2 \%$ bovine serum albumin [17]. This was followed by adipocyte mRNA extraction using RNeasy Lipid Tissue Mini Kit (Qiagen, Nordic, Solletuna, Sweden) with a DNase I (Qiagen) digestion according to the manufacturer's instructions.

\subsection{Adipocyte Morphology}

Fresh SAT biopsy specimens were digested with $2 \%$ collagenase in DMEM/F12 with supplements [17] and 2\% bovine serum albumin (as above) and were used for measurement and calculation of adipocyte size in all 12 discordant twin pairs, as before [17]. After collagenase treatment, the digests were washed and maintained in the above medium and images of live adipocytes were taken with a light microscope (Zeiss, Axioplan2) using 50× magnification. A minimum of 200 cells were measured for diameter using an image processing and analysis software ImageJ (Image J 1.42q/Java 1. 6.0_10 32-bit), as previously described [17].

\subsection{Affymetrix Transcriptomics}

A total of $500 \mathrm{ng}$ of RNA from adipocyte-enriched fraction, isolated as described above, was used for gene expression analysis on an Affymetrix U133 Plus 2.0 array (Thermo Fischer, Santa Clara, CA, USA) according to the manufacturer's instructions and validated as described previously [45]. Hybridization, staining, and washing were performed using the Affymetrics Fluidics Station 450 and Hybridization 
oven 640 under standard conditions. Expression data was pre-processed with BioConductor software (open source, www.bioconductor.org) and the GC-RMA algorithm [106].

\subsection{Transcriptome-Wide Association Study, Statistics, and Bioinformatics}

Intra-pair values ( $\Delta$ Heavy-Lean) for twins' transcriptome (differential gene expression, $\Delta$ ) were calculated and screened for correlation to intra-pair $\triangle F 13 A 1$ expression in adipocyte-enriched fraction using R Statistical Software (https://www.r-project.org/) [107]. Significance within the TGM family (TGM1-7 and F13A1) expression in twin pairs was calculated via analysis of variance (ANOVA) with Bonferroni post-test using Prism GraphPad software (release 8.0, San Diego, CA, USA). $p$-Values $<0.05$ were considered significant. Pearson $(\mathrm{r})$ correlation and $\mathrm{r}^{2}$ parameters were obtained for $\triangle F 13 A 1$ and $\triangle$ Adipocyte Diameter, and those with $\mathrm{r}^{2}>0.5$ and associated $p$-values $<0.05$ were considered for further screening. Normal distribution of $F 13 A 1 \mathrm{mRNA}$ expression values and adipocyte diameter values were assessed as before [30]. Significance of differential gene expression between the co-twins was tested with a paired T-test and associated $p$-values $<0.05$ were considered significant. Further linear regression analysis was performed for selected genes with significant associations to $\triangle F 13 A 1$ with Prism GraphPad software (release 8.0, San Diego, CA, USA). Here, $p$-values were considered significant as follows: ${ }^{*} p<0.05,{ }^{* *} p<0.01,{ }^{* * *} p<0.001,{ }^{* * * *} p<0.0001$. Gene Ontology enrichment analysis and GOterm cluster analysis for over-represented genes from transcriptome screening was performed using Panther, GOnet, and Gorilla online tools. Significance for GOterms is represented in False Discovery Rate (FDR) adjusted $p$-values.

Supplementary Materials: The following are available online at http://www.mdpi.com/1422-0067/21/21/8289/s1. References $[17,31,108-120]$ are cited in the supplementary materials.

Author Contributions: Conceptualization, Writing, Review and Editing, Data Analysis and Funding Acquisition, M.T.K.; Conceptualization, Writing, Review and Editing, Clinical Data Collection, Data Analysis, K.H.P.; Data Analysis, Writing, S.H.; Data Analysis, M.A.; Clinical Data Collection, A.R. and J.K. All authors have read and agreed to the published version of the manuscript.

Funding: This study has been supported by a grant to M.T.K. from the Canadian Institutes of Health Research (CIHR) (MOP-119403). M.A. is supported by an internal stipend, Nyman Award, from the Faculty of Medicine of McGill University. S.H. was supported by Finnish Diabetes Research Foundation, Emil Aaltonen Foundation, Finnish Medical Foundation, Maud Kuistila Foundation, Orion Foundation, Paulo foundation and Helsinki University Hospital funds. K.H.P. is funded by the Academy of Finland, grant numbers 314383, 266286, and the Academy of Finland, Centre of Excellence in Research on Mitochondria, Metabolism and Disease (FinMIT), grant number 272376, the Finnish Medical Foundation, the Gyllenberg Foundation, the Novo Nordisk Foundation, grant numbers NNF17OC0027232, NNF10OC1013354, the Finnish Diabetes Research Foundation, the Finnish Foundation for Cardiovascular Research, the University of Helsinki, Government Research Funds and Helsinki University Hospital.

Conflicts of Interest: The authors declare no conflict of interest.

\section{References}

1. Eckert, R.L.; Kaartinen, M.T.; Nurminskaya, M.; Belkin, A.M.; Colak, G.; Johnson, G.V.W.; Mehta, K. Transglutaminase Regulation of Cell Function. Physiol. Rev. 2014, 94, 383-417. [CrossRef]

2. Iismaa, S.E.; Mearns, B.M.; Lorand, L.; Graham, R.M. Transglutaminases and Disease: Lessons from Genetically Engineered Mouse Models and Inherited Disorders. Physiol. Rev. 2009, 89, 991-1023. [CrossRef] [PubMed]

3. Muszbek, L.; Bereczky, Z.; Bagoly, Z.; Komáromi, I.; Katona, É. Factor XIII: A Coagulation Factor with Multiple Plasmatic and Cellular Functions. Physiol. Rev. 2011, 91, 931-972. [CrossRef] [PubMed]

4. Lorand, L.; Graham, R.M. Transglutaminases: Crosslinking enzymes with pleiotropic functions. Nat. Rev. Mol. Cell Biol. 2003, 4, 140-156. [CrossRef] [PubMed]

5. Forsprecher, J.; Wang, Z.; Goldberg, H.A.; Kaartinen, M.T. Transglutaminase-mediated oligomerization promotes osteoblast adhesive properties of osteopontin and bone sialoprotein. Cell Adhes. Migr. 2011, 5, 65-72. [CrossRef] [PubMed] 
6. Kaartinen, M.T.; Pirhonen, A.; Linnala-Kankkunen, A.; Mäenpää, P.H. Cross-linking of Osteopontin by Tissue Transglutaminase Increases Its Collagen Binding Properties. J. Biol. Chem. 1999, 274, 1729-1735. [CrossRef] [PubMed]

7. Nelea, V.; Nakano, Y.; Kaartinen, M.T. Size Distribution and Molecular Associations of Plasma Fibronectin and Fibronectin Crosslinked by Transglutaminase. Protein J. 2008, 27, 223-233. [CrossRef]

8. Kanchan, K.; Fuxreiter, M.; Fésüs, L. Physiological, pathological, and structural implications of non-enzymatic protein-protein interactions of the multifunctional human transglutaminase. Cell. Mol. Life Sci. 2015, 72, 3009-3035. [CrossRef] [PubMed]

9. Kaartinen, M.T.; El-Maadawy, S.; Räsänen, N.H.; McKee, M.D. Tissue Transglutaminase and Its Substrates in Bone. J. Bone Miner. Res. 2002, 17, 2161-2173. [CrossRef] [PubMed]

10. Mousa, A.; Cui, C.; Song, A.; Myneni, V.D.; Sun, H.; Li, J.J.; Murshed, M.; Melino, G.; Kaartinen, M.T. Transglutaminases factor XIII-A and TG2 regulate resorption, adipogenesis and plasma fibronectin homeostasis in bone and bone marrow. Cell Death Differ. 2017, 24, 844-854. [CrossRef]

11. Nurminskaya, M. Transglutaminases in mineralized tissues. Front. Biosci. 2006, 11, 1591. [CrossRef] [PubMed]

12. Al-Jallad, H.F.; Myneni, V.D.; Piercy-Kotb, S.A.; Chabot, N.; Mulani, A.; Keillor, J.W.; Kaartinen, M.T. Plasma Membrane Factor XIIIA Transglutaminase Activity Regulates Osteoblast Matrix Secretion and Deposition by Affecting Microtubule Dynamics. PLoS ONE 2011, 6, e15893. [CrossRef]

13. Cui, C.; Wang, S.; Myneni, V.D.; Hitomi, K.; Kaartinen, M.T. Transglutaminase activity arising from Factor XIIIA is required for stabilization and conversion of plasma fibronectin into matrix in osteoblast cultures. Bone 2014, 59, 127-138. [CrossRef] [PubMed]

14. Heath, D.J.; Downes, S.; Verderio, E.; Griffin, M. Characterization of Tissue Transglutaminase in Human Osteoblast-like Cells. J. Bone Miner. Res. 2001, 16, 1477-1485. [CrossRef]

15. Piercy-Kotb, S.A.; Mousa, A.; Al-Jallad, H.F.; Myneni, V.D.; Chicatun, F.; Nazhat, S.N.; Kaartinen, M.T. Factor XIIIA transglutaminase expression and secretion by osteoblasts is regulated by extracellular matrix collagen and the MAP kinase signaling pathway. J. Cell. Physiol. 2012, 227, 2936-2946. [CrossRef]

16. Cristancho, A.G.; Lazar, M.A. Forming functional fat: A growing understanding of adipocyte differentiation. Nat. Rev. Mol. Cell Biol. 2011, 12, 722-734. [CrossRef] [PubMed]

17. Heinonen, S.; Saarinen, L.; Naukkarinen, J.; Rodríguez, A.; Frühbeck, G.; Hakkarainen, A.; Lundbom, J.; Lundbom, N.; Vuolteenaho, K.; Moilanen, E.; et al. Adipocyte morphology and implications for metabolic derangements in acquired obesity. Int. J. Obes. 2014, 38, 1423-1431. [CrossRef]

18. Tandon, P.; Wafer, R.; Minchin, J.E.N. Adipose morphology and metabolic disease. J. Exp. Biol. 2018, 221, jeb164970. [CrossRef]

19. Yin, X.; Lanza, I.R.; Swain, J.M.; Sarr, M.G.; Nair, K.S.; Jensen, M.D. Adipocyte Mitochondrial Function Is Reduced in Human Obesity Independent of Fat Cell Size. J. Clin. Endocrinol. Metab. 2014, 99, E209-E216. [CrossRef]

20. Xiao, L.; Yang, X.; Lin, Y.; Li, S.; Jiang, J.; Qian, S.; Tang, Q.; He, R.; Li, X. Large adipocytes function as antigen-presenting cells to activate CD4+ T cells via upregulating MHCII in obesity. Int. J. Obes. 2015, 40, 112-120. [CrossRef]

21. Engin, A.B. What Is Lipotoxicity? Adv. Exp. Med. Biol. 2017, 960, 197-220.

22. Engin, A.B. Adipocyte-Macrophage Cross-Talk in Obesity. Adv. Exp. Med. Biol. 2017, 960, 327-343. [CrossRef] [PubMed]

23. Kahn, S.E.; Hull, R.L.; Utzschneider, K.M. Mechanisms linking obesity to insulin resistance and type 2 diabetes. Nat. Cell Biol. 2006, 444, 840-846. [CrossRef] [PubMed]

24. Sun, K.; Kusminski, C.M.; Scherer, P.E. Adipose tissue remodeling and obesity. J. Clin. Investig. 2011, 121, 2094-2101. [CrossRef]

25. Myneni, V.D.; Melino, G.; Kaartinen, M.T. Transglutaminase 2-A novel inhibitor of adipogenesis. Cell Death Dis. 2015, 6, e1868. [CrossRef]

26. Sághy, T.; Köröskényi, K.; Hegedús, K.; Antal, M.; Bankó, C.; Bacsó, Z.; Papp, A.; Stienstra, R.; Szondy, Z. Loss of transglutaminase 2 sensitizes for diet-induced obesity-related inflammation and insulin resistance due to enhanced macrophage c-Src signaling. Cell Death Dis. 2019, 10, 439. [CrossRef] 
27. Naukkarinen, J.; Surakka, I.; Pietiläinen, K.H.; Rissanen, A.; Salomaa, V.; Ripatti, S.; Yki-Jarvinen, H.; Van Duijn, C.M.; Wichmann, H.-E.; Kaprio, J.; et al. Use of Genome-Wide Expression Data to Mine the "Gray Zone" of GWA Studies Leads to Novel Candidate Obesity Genes. PLoS Genet. 2010, 6, e1000976. [CrossRef] [PubMed]

28. Myneni, V.D.; Hitomi, K.; Kaartinen, M.T. Factor XIII-A transglutaminase acts as a switch between preadipocyte proliferation and differentiation. Blood 2014, 124, 1344-1353. [CrossRef]

29. Myneni, V.D.; Mousa, A.; Kaartinen, M.T. Factor XIII-A transglutaminase deficient mice show signs of metabolically healthy obesity on high fat diet. Sci. Rep. 2016, 6, 35574. [CrossRef]

30. Kaartinen, A.; Heinonen, L.; Hakkarainen, L.; Rissanen, K.; Pietiläinen, K.H. F13A1 transglutaminase expression in human adipose tissue increases in acquired excess weight and associates with inflammatory status of adipocytes. Int. J. Obes. in press.

31. Jernås, M.; Palming, J.; Sjöholm, K.; Jennische, E.; Svensson, P.-A.; Gabrielsson, B.G.; Levin, M.; Sjögren, A.; Rudemo, M.; Lystig, T.C.; et al. Separation of human adipocytes by size: Hypertrophic fat cells display distinct gene expression. FASEB J. 2006, 20, 1540-1542. [CrossRef]

32. Lee, B.-C.; Lee, J. Cellular and molecular players in adipose tissue inflammation in the development of obesity-induced insulin resistance. Biochim. Biophys. Acta (BBA) Mol. Basis Dis. 2014, 1842, 446-462. [CrossRef] [PubMed]

33. Burhans, M.S.; Hagman, D.K.; Kuzma, J.N.; Schmidt, K.A.; Kratz, M. Contribution of Adipose Tissue Inflammation to the Development of Type 2 Diabetes Mellitus. Compr. Physiol. 2018, 9, 1-58. [CrossRef]

34. Reilly, S.M.; Saltiel, A.R. Adapting to obesity with adipose tissue inflammation. Nat. Rev. Endocrinol. 2017, 13, 633-643. [CrossRef]

35. Stolarczyk, E. Adipose tissue inflammation in obesity: A metabolic or immune response? Curr. Opin. Pharmacol. 2017, 37, 35-40. [CrossRef]

36. Trim, W.; Turner, J.E.; Thompson, D. Parallels in Immunometabolic Adipose Tissue Dysfunction with Ageing and Obesity. Front. Immunol. 2018, 9, 169. [CrossRef]

37. Caccamo, D.; Currò, M.; Ferlazzo, N.; Condello, S.; Ientile, R. Monitoring of transglutaminase 2 under different oxidative stress conditions. Amino Acids 2011, 42, 1037-1043. [CrossRef] [PubMed]

38. Currò, M.; Ferlazzo, N.; Risitano, R.; Condello, S.; Vecchio, M.; Caccamo, D.; Ientile, R. Transglutaminase 2 and phospholipase A2 interactions in the inflammatory response in human Thp-1 monocytes. Amino Acids 2013, 46, 759-766. [CrossRef]

39. Ientile, R.; Caccamo, D.; Griffin, M. Tissue transglutaminase and the stress response. Amino Acids 2007, 33, 385-394. [CrossRef]

40. Heinonen, S.; Buzkova, J.; Muniandy, M.; Kaksonen, R.; Ollikainen, M.; Ismail, K.; Hakkarainen, A.; Lundbom, J.; Lundbom, N.; Vuolteenaho, K.; et al. Impaired Mitochondrial Biogenesis in Adipose Tissue in Acquired Obesity. Diabetes 2015, 64, 3135-3145. [CrossRef]

41. Heinonen, S.; Jokinen, R.; Rissanen, A.; Pietiläinen, K.H. White adipose tissue mitochondrial metabolism in health and in obesity. Obes. Rev. 2019, 21, e12958. [CrossRef]

42. Heinonen, S.; Muniandy, M.; Buzkova, J.; Mardinoglu, A.; Rodríguez, A.; Frühbeck, G.; Hakkarainen, A.; Lundbom, J.; Lundbom, N.; Kaprio, J.; et al. Mitochondria-related transcriptional signature is downregulated in adipocytes in obesity: A study of young healthy MZ twins. Diabetology 2016, 60, 169-181. [CrossRef]

43. Jukarainen, S.; Heinonen, S.; Rämö, J.T.; Rinnankoski-Tuikka, R.; Rappou, E.; Tummers, M.; Muniandy, M.; Hakkarainen, A.; Lundbom, J.; Lundbom, N.; et al. Obesity Is Associated With Low NAD(+)/SIRT Pathway Expression in Adipose Tissue of BMI-Discordant Monozygotic Twins. J. Clin. Endocrinol. Metab. 2016, 101, 275-283. [CrossRef]

44. Kaye, S.M.; Pietiläinen, K.H.; Kotronen, A.; Joutsi-Korhonen, L.; Kaprio, J.; Yki-Järvinen, H.; Silveira, A.; Hamsten, A.; Lassila, R.; Rissanen, A. Obesity-Related Derangements of Coagulation and Fibrinolysis: A Study of Obesity-Discordant Monozygotic Twin Pairs. Obesity 2012, 20, 88-94. [CrossRef]

45. Naukkarinen, J.; Heinonen, S.; Hakkarainen, A.; Lundbom, J.; Vuolteenaho, K.; Saarinen, L.; Hautaniemi, S.; Rodríguez, A.; Frühbeck, G.; Pajunen, P.; et al. Characterising metabolically healthy obesity in weight-discordant monozygotic twins. Diabetology 2013, 57, 167-176. [CrossRef] 
46. Pietiläinen, K.H.; Ismail, K.; Järvinen, E.; Heinonen, S.; Tummers, M.; Bollepalli, S.; Lyle, R.; Muniandy, M.; Moilanen, E.; Hakkarainen, A.; et al. DNA methylation and gene expression patterns in adipose tissue differ significantly within young adult monozygotic BMI-discordant twin pairs. Int. J. Obes. 2015, 40, 654-661. [CrossRef]

47. Sahebekhtiari, N.; Saraswat, M.; Joenväärä, S.; Jokinen, R.; Lovric, A.; Kaye, S.; Mardinoglu, A.; Rissanen, A.; Kaprio, J.; Renkonen, R.; et al. Plasma Proteomics Analysis Reveals Dysregulation of Complement Proteins and Inflammation in Acquired Obesity—A Study on Rare BMI-Discordant Monozygotic Twin Pairs. Proteom. Clin. Appl. 2019, 13, e1800173. [CrossRef]

48. Church, C.D.; Berry, R.; Rodeheffer, M.S. Isolation and Study of Adipocyte Precursors. Methods Enzymol. 2014, 537, 31-46. [CrossRef]

49. Hagberg, C.E.; Li, Q.; Kutschke, M.; Bhowmick, D.; Kiss, E.; Shabalina, I.G.; Harms, M.J.; Shilkova, O.; Kozina, V.; Nedergaard, J.; et al. Flow Cytometry of Mouse and Human Adipocytes for the Analysis of Browning and Cellular Heterogeneity. Cell Rep. 2018, 24, 2746-2756.e5. [CrossRef]

50. Martin, J.; Collot-Teixeira, S.; McGregor, L.; McGregor, J.L. The dialogue between endothelial cells and monocytes/macrophages in vascular syndromes. Curr. Pharm. Des. 2007, 13, 1751-1759. [CrossRef]

51. Bagoly, Z.; Katona, É.; Muszbek, L. Factor XIII and inflammatory cells. Thromb. Res. 2012, 129, S77-S81. [CrossRef] [PubMed]

52. Sun, H.; Kaartinen, M.T. Transglutaminases in Monocytes and Macrophages. Med. Sci. 2018, 6, 115. [CrossRef]

53. Mitchell, J.L.; Mutch, N.J. Let's cross-link: Diverse functions of the promiscuous cellular transglutaminase factor XIII-A. J. Thromb. Haemost. 2019, 17, 19-30. [CrossRef]

54. Dardik, R.; Inbal, A. Complex formation between tissue transglutaminase II (tTG) and vascular endothelial growth factor receptor 2 (VEGFR-2): Proposed mechanism for modulation of endothelial cell response to VEGF. Exp. Cell Res. 2006, 312, 2973-2982. [CrossRef]

55. Dardik, R.; Leor, J.; Skutelsky, E.; Castel, D.; Holbova, R.; Schiby, G.; Shaish, A.; Dickneite, G.; Loscalzo, J.; Inbal, A. Evaluation of the pro-angiogenic effect of factor XIII in heterotopic mouse heart allografts and FXIII-deficient mice. Thromb. Haemost. 2006, 95, 546-550. [CrossRef] [PubMed]

56. Dardik, R.; Loscalzo, J.; Inbal, A. Factor XIII (FXIII) and angiogenesis. J. Thromb. Haemost. 2005, 4, 19-25. [CrossRef]

57. Dardik, R.; Shenkman, B.; Tamarin, I.; Eskaraev, R.; Harsfalvi, J.; Varon, D.; Inbal, A. Factor XIII mediates adhesion of platelets to endothelial cells through alpha(v)beta(3) and glycoprotein IIb/IIIa integrins. Thromb. Res. 2002, 105, 317-323. [CrossRef]

58. Dardik, R.; Solomon, A.; Loscalzo, J.; Eskaraev, R.; Bialik, A.; Goldberg, I.; Schiby, G.; Inbal, A. Novel Proangiogenic Effect of Factor XIII Associated With Suppression of Thrombospondin 1 Expression. Arter. Thromb. Vasc. Biol. 2003, 23, 1472-1477. [CrossRef]

59. Inbal, A.; Dardik, R. Role of Coagulation Factor XIII (FXIII) in Angiogenesis and Tissue Repair. Pathophysiol. Haemost. Thromb. 2006, 35, 162-165. [CrossRef]

60. Akira, S.; Misawa, T.; Satoh, T. Macrophages control innate inflammation. Diabetes Obes. Metab. 2013, 15, 10-18. [CrossRef]

61. Wen, H.; Gris, D.; Lei, Y.; Jha, S.; Zhang, L.; Huang, M.T.-H.; Brickey, W.J.; Ting, J.P.-Y. Fatty acid-induced NLRP3-ASC inflammasome activation interferes with insulin signaling. Nat. Immunol. 2011, 12, 408-415. [CrossRef] [PubMed]

62. Rheinheimer, J.; De Souza, B.M.; Cardoso, N.S.; Bauer, A.C.; Crispim, D. Current role of the NLRP3 inflammasome on obesity and insulin resistance: A systematic review. Metabolism 2017, 74, 1-9. [CrossRef] [PubMed]

63. Camell, C.D.; Günther, P.; Lee, A.; Goldberg, E.L.; Spadaro, O.; Youm, Y.-H.; Bartke, A.; Hubbard, G.B.; Ikeno, Y.; Ruddle, N.H.; et al. Aging Induces an Nlrp3 Inflammasome-Dependent Expansion of Adipose B Cells That Impairs Metabolic Homeostasis. Cell Metab. 2019, 30, 1024-1039.e6. [CrossRef]

64. Stienstra, R.; Van Diepen, J.A.; Tack, C.J.; Zaki, M.H.; Van De Veerdonk, F.L.; Perera, D.; Neale, G.A.; Hooiveld, G.J.; Hijmans, A.; Vroegrijk, I.; et al. Inflammasome is a central player in the induction of obesity and insulin resistance. Proc. Natl. Acad. Sci. USA 2011, 108, 15324-15329. [CrossRef] 
65. Ballak, D.B.; Stienstra, R.; Tack, C.J.; Dinarello, C.A.; Van Diepen, J.A. IL-1 family members in the pathogenesis and treatment of metabolic disease: Focus on adipose tissue inflammation and insulin resistance. Cytokine 2015, 75, 280-290. [CrossRef]

66. Castanheira, F.V.S.; Kubes, P. Neutrophils and NETs in modulating acute and chronic inflammation. Blood 2019, 133, 2178-2185. [CrossRef] [PubMed]

67. Kolaczkowska, E.; Kubes, P. Neutrophil recruitment and function in health and inflammation. Nat. Rev. Immunol. 2013, 13, 159-175. [CrossRef]

68. Liew, P.X.; Kubes, P. The Neutrophil's Role During Health and Disease. Physiol. Rev. 2019, 99, $1223-1248$. [CrossRef]

69. Mantovani, A.; Cassatella, M.A.; Costantini, C.; Jaillon, S. Neutrophils in the activation and regulation of innate and adaptive immunity. Nat. Rev. Immunol. 2011, 11, 519-531. [CrossRef]

70. Maurizi, G.; Della Guardia, L.; Maurizi, A.; Poloni, A. Adipocytes properties and crosstalk with immune system in obesity-related inflammation. J. Cell. Physiol. 2017, 233, 88-97. [CrossRef]

71. Watanabe, Y.; Nagai, Y.; Honda, H.; Okamoto, N.; Yanagibashi, T.; Ogasawara, M.; Yamamoto, S.; Imamura, R.; Takasaki, I.; Hara, H.; et al. Bidirectional crosstalk between neutrophils and adipocytes promotes adipose tissue inflammation. FASEB J. 2019, 33, 11821-11835. [CrossRef]

72. Hook, J.S.; Cao, M.; Potera, R.M.; Alsmadi, N.Z.; Schmidtke, D.W.; Moreland, J.G. Nox2 Regulates Platelet Activation and NET Formation in the Lung. Front. Immunol. 2019, 10, 1472. [CrossRef]

73. Han, C.Y. Roles of Reactive Oxygen Species on Insulin Resistance in Adipose Tissue. Diabetes Metab. J. 2016, 40, 272-279. [CrossRef]

74. Srikakulapu, P.; McNamara, C.A. B Lymphocytes and Adipose Tissue Inflammation. Arter. Thromb. Vasc. Biol. 2020, 40, 1110-1122. [CrossRef]

75. Winer, D.A.; Winer, S.; Chng, M.H.Y.; Shen, L.; Engleman, E.G. B Lymphocytes in obesity-related adipose tissue inflammation and insulin resistance. Cell. Mol. Life Sci. 2013, 71, 1033-1043. [CrossRef]

76. Kim, Y.-H.; Choi, B.-H.; Cheon, H.-G.; Do, M.-S. B cell activation factor (BAFF) is a novel adipokine that links obesity and inflammation. Exp. Mol. Med. 2009, 41, 208-216. [CrossRef]

77. Esnault, S.; Kelly, E.A.; Sorkness, R.L.; Evans, M.D.; Busse, W.W.; Jarjour, N.N. Airway factor XIII associates with type 2 inflammation and airway obstruction in asthmatic patients. J. Allergy Clin. Immunol. 2016, 137, 767-773.e6. [CrossRef]

78. Gualtierotti, R.; Ingegnoli, F.; Boscolo, M.; Griffini, S.; Grovetti, E.; Cugno, M. Tocilizumab Effects on Coagulation Factor XIII in Patients with Rheumatoid Arthritis. Adv. Ther. 2019, 36, 3494-3502. [CrossRef]

79. Ichinose, A. Factor XIII is a key molecule at the intersection of coagulation and fibrinolysis as well as inflammation and infection control. Int. J. Hematol. 2012, 95, 362-370. [CrossRef] [PubMed]

80. Kovar, F.M.; Marsik, C.L.; Jilma, B.; Mannhalter, C.; Joukhadar, C.; Wagner, O.F.; Endler, G. The inflammatory response is influenced by FXIII VAL 34 LEU polymorphism in a human LPS model. Wien. Klin. Wochenschr. 2009, 121, 515-519. [CrossRef]

81. Raghu, H.; Cruz, C.; Rewerts, C.L.; Frederick, M.D.; Thornton, S.; Mullins, E.S.; Schoenecker, J.G.; Degen, J.L.; Flick, M.J. Transglutaminase factor XIII promotes arthritis through mechanisms linked to inflammation and bone erosion. Blood 2015, 125, 427-437. [CrossRef]

82. Soendergaard, C.; Kvist, P.H.; Seidelin, J.B.; Pelzer, H.; Nielsen, O.H. Systemic and intestinal levels of factor XIII-A: The impact of inflammation on expression in macrophage subtypes. J. Gastroenterol. 2015, 51, 796-807. [CrossRef]

83. Kopec, A.K.; Abrahams, S.R.; Thornton, S.; Palumbo, J.S.; Mullins, E.S.; Divanovic, S.; Weiler, H.; Owens, A.P.; Mackman, N.; Goss, A.M.; et al. Thrombin promotes diet-induced obesity through fibrin-driven inflammation. J. Clin. Investig. 2017, 127, 3152-3166. [CrossRef] [PubMed]

84. Porrello, A.; Leslie, P.L.; Harrison, E.B.; Gorentla, B.K.; Kattula, S.; Ghosh, S.K.; Azam, S.H.; Holtzhausen, A.; Chao, Y.L.; Hayward, M.C.; et al. Factor XIIIA-expressing inflammatory monocytes promote lung squamous cancer through fibrin cross-linking. Nat. Commun. 2018, 9, 1988. [CrossRef]

85. Lanir, N.; Ciano, P.S.; Van De Water, L.; McDonagh, J.; Dvorak, A.M.; Dvorak, H.F. Macrophage migration in fibrin gel matrices. II. Effects of clotting factor XIII, fibronectin, and glycosaminoglycan content on cell migration. J. Immunol. 1988, 140, 2340-2349. [PubMed]

86. Goldstein, B.J. Protein-Tyrosine phosphatases and the regulation of insulin action. J. Cell. Biochem. 1992, 48, 33-42. [CrossRef] [PubMed] 
87. Goldstein, B.J.; Ahmad, F.; Ding, W.; Li, P.-M.; Zhang, W.-R. Regulation of the insulin signalling pathway by cellular protein-tyrosine phosphatases. Mol. Cell. Biochem. 1998, 182, 91-99. [CrossRef]

88. Kim, W.-K.; Jung, H.; Kim, D.-H.; Kim, E.-Y.; Chung, J.-W.; Cho, Y.-S.; Park, S.G.; Park, B.-C.; Ko, Y.; Bae, K.-H.; et al. Regulation of adipogenic differentiation by LAR tyrosine phosphatase in human mesenchymal stem cells and 3T3-L1 preadipocytes. J. Cell Sci. 2009, 122, 4160-4167. [CrossRef]

89. Ren, J.M.; Li, P.M.; Zhang, W.R.; Sweet, L.J.; Cline, G.; Shulman, G.I.; Livingston, J.N.; Goldstein, B.J. Transgenic mice deficient in the LAR protein-tyrosine phosphatase exhibit profound defects in glucose homeostasis. Diabetes 1998, 47, 493-497. [CrossRef]

90. Deng, T.; Lyon, C.J.; Minze, L.J.; Lin, J.; Zou, J.; Liu, J.Z.; Ren, Y.; Yin, Z.; Hamilton, D.J.; Reardon, P.R.; et al. Class II Major Histocompatibility Complex Plays an Essential Role in Obesity-Induced Adipose Inflammation. Cell Metab. 2013, 17, 411-422. [CrossRef]

91. Poloni, A.; Maurizi, G.; Ciarlantini, M.; Medici, M.; Mattiucci, D.; Mancini, S.; Maurizi, A.; Falconi, M.; Olivieri, A.; Leoni, P. Interaction between human mature adipocytes and lymphocytes induces T-cell proliferation. Cytotherapy 2015, 17, 1292-1301. [CrossRef]

92. Datta, R.; Podolsky, M.J.; Atabai, K. Fat fibrosis: Friend or foe? JCI Insight 2018, 3, e122289. [CrossRef]

93. Khan, T.; Muise, E.S.; Iyengar, P.; Wang, Z.V.; Chandalia, M.; Abate, N.; Zhang, B.B.; Bonaldo, P.; Chua, S.; Scherer, P.E. Metabolic Dysregulation and Adipose Tissue Fibrosis: Role of Collagen VI. Mol. Cell. Biol. 2008, 29, 1575-1591. [CrossRef]

94. Lin, D.; Chun, T.-H.; Kang, L. Adipose extracellular matrix remodelling in obesity and insulin resistance. Biochem. Pharmacol. 2016, 119, 8-16. [CrossRef]

95. Crewe, C.; An, Y.A.; Scherer, P.E. The ominous triad of adipose tissue dysfunction: Inflammation, fibrosis, and impaired angiogenesis. J. Clin. Investig. 2017, 127, 74-82. [CrossRef]

96. Ruiz-Ojeda, F.J.; Méndez-Gutiérrez, A.; Aguilera, C.M.; Plaza-Díaz, J. Extracellular Matrix Remodeling of Adipose Tissue in Obesity and Metabolic Diseases. Int. J. Mol. Sci. 2019, 20, 4888. [CrossRef]

97. Cinti, S.; Mitchell, G.; Barbatelli, G.; Murano, I.; Ceresi, E.; Faloia, E.; Wang, S.; Fortier, M.; Greenberg, A.S.; Obin, M.S. Adipocyte death defines macrophage localization and function in adipose tissue of obese mice and humans. J. Lipid Res. 2005, 46, 2347-2355. [CrossRef]

98. Trayhurn, P. Hypoxia and Adipose Tissue Function and Dysfunction in Obesity. Physiol. Rev. 2013, 93, 1-21. [CrossRef]

99. Sato, H.; Taketomi, Y.; Murakami, M. Metabolic regulation by secreted phospholipase A. Inflamm. Regen. 2016, 36, 7. [CrossRef]

100. Iyer, A.; Lim, J.; Poudyal, H.; Reid, R.C.; Suen, J.Y.; Webster, J.; Prins, J.B.; Whitehead, J.P.; Fairlie, D.; Brown, L. An Inhibitor of Phospholipase A2 Group IIA Modulates Adipocyte Signaling and Protects Against Diet-Induced Metabolic Syndrome in Rats. Diabetes 2012, 61, 2320-2329. [CrossRef]

101. Zhang, T.; He, J.; Xu, C.; Zu, L.; Jiang, H.; Pu, S.; Guo, X.; Xu, G. Mechanisms of metformin inhibiting lipolytic response to isoproterenol in primary rat adipocytes. J. Mol. Endocrinol. 2008, 42, 57-66. [CrossRef]

102. Greenberg, A.S.; Shen, W.-J.; Muliro, K.; Patel, S.; Souza, S.C.; Roth, R.A.; Kraemer, F.B. Stimulation of Lipolysis and Hormone-sensitive Lipase via the Extracellular Signal-regulated Kinase Pathway. J. Biol. Chem. 2001, 276, 45456-45461. [CrossRef]

103. Hesselbarth, N.; Kunath, A.; Kern, M.; Gericke, M.; Mejhert, N.; Rydén, M.; Stumvoll, M.; Blüher, M.; Klöting, N. Repin1 deficiency in adipose tissue improves whole-body insulin sensitivity, and lipid metabolism. Int. J. Obes. 2017, 41, 1815-1823. [CrossRef]

104. Kaprio, J. Twin studies in Finland Twin research and human genetics. Off. J. Int. Soc. Twin Stud. 2006, 9, 772-777.

105. Granér, M.; Seppälä-Lindroos, A.; Rissanen, A.; Hakkarainen, A.; Lundbom, N.; Kaprio, J.; Nieminen, M.S.; Pietiläinen, K.H. Epicardial Fat, Cardiac Dimensions, and Low-Grade Inflammation in Young Adult Monozygotic Twins Discordant for Obesity. Am. J. Cardiol. 2012, 109, 1295-1302. [CrossRef]

106. Gentleman, R.C.; Carey, V.; Bates, D.; Bolstad, B.; Dettling, M.; Dudoit, S.; Ellis, B.; Gautier, L.; Ge, Y.; Gentry, J.; et al. Bioconductor: Open software development for computational biology and bioinformatics. Genome Biol. 2004, 5, R80. [CrossRef]

107. R Core Team. R: A Language and Environment for Statistical Computing; R Foundation for Statistical Computing: Vienna, Austria, 2011. 
108. Zhang, Y.; Xie, L.; Gunasekar, S.K.; Tong, D.; Mishra, A.; Gibson, W.J.; Wang, C.; Fidler, T.; Marthaler, B.; Klingelhutz, A.; et al. SWELL1 is a regulator of adipocyte size, insulin signalling and glucose homeostasis. Nat. Cell Biol. 2017, 19, 504-517. [CrossRef]

109. Abreu-Vieira, G.; Fischer, A.W.; Mattsson, C.; De Jong, J.M.; Shabalina, I.G.; Rydén, M.; Laurencikiene, J.; Arner, P.; Cannon, B.; Nedergaard, J.; et al. Cidea improves the metabolic profile through expansion of adipose tissue. Nat. Commun. 2015, 6, 7433. [CrossRef]

110. Weingarten, A.; Turchetti, L.; Krohn, K.; Klöting, I.; Kern, M.; Kovacs, P.; Stumvoll, M.; Blüher, M.; Klöting, N. Novel genes on rat chromosome 10 are linked to body fat mass, preadipocyte number and adipocyte size. Int. J. Obes. (2005) 2016, 40, 1832-1840. [CrossRef]

111. Lundbäck, V.; Kulyté, A.; Strawbridge, R.J.; Ryden, M.; Arner, P.; Marcus, C.; Dahlman, I. FAM13A and POM121C are candidate genes for fasting insulin: Functional follow-up analysis of a genome-wide association study. Diabetol. 2018, 61, 1112-1123. [CrossRef]

112. Krautbauer, S.; Neumeier, M.; Rein-Fischboeck, L.; Haberl, E.M.; Tilg, H.; Eisinger, K.; Buechler, C. Adipocyte Hypertrophy and Improved Postprandial Lipid Response in Beta 2 Syntrophin Deficient Mice. Cell. Physiol. Biochem. 2019, 52, 1151-1165. [CrossRef]

113. Geoghegan, G.; Simcox, J.; Seldin, M.M.; Parnell, T.J.; Stubben, C.; Just, S.; Begaye, L.; Lusis, A.J.; Villanueva, C.J. Targeted deletion of Tcf7l2 in adipocytes promotes adipocyte hypertrophy and impaired glucose metabolism. Mol. Metab. 2019, 24, 44-63. [CrossRef] [PubMed]

114. Kilian, T.M.; Klöting, N.; Blüher, M.; Beck-Sickinger, A.G. Prenatal notch1 receptor blockade by protein delta homolog 1 (DLK1) modulates adipocyte size in vivo. Int. J. Obes. 2015, 40, 698-705. [CrossRef]

115. Longo, M.; Raciti, G.A.; Zatterale, F.; Parrillo, L.; Desiderio, A.; Spinelli, R.; Hammarstedt, A.; Hedjazifar, S.; Hoffmann, J.M.; Nigro, C.; et al. Epigenetic modifications of the Zfp/ZNF423 gene control murine adipogenic commitment and are dysregulated in human hypertrophic obesity. Diabetologia 2018, 61, 369-380. [CrossRef]

116. Huang, Z.H.; Gu, D.; Mazzone, T. Role of adipocyte-derived apoE in modulating adipocyte size, lipid metabolism, and gene expression in vivo. Am. J. Physiol. Metab. 2009, 296, E1110-E1119. [CrossRef]

117. Acosta, J.R.; Douagi, I.; Andersson, D.P.; Bäckdahl, J.; Rydén, M.; Arner, P.; Laurencikiene, J. Increased fat cell size: A major phenotype of subcutaneous white adipose tissue in non-obese individuals with type 2 diabetes. Diabetologia 2015, 59, 560-570. [CrossRef]

118. Ruschke, K.; Illes, M.; Kern, M.; Klöting, I.; Fasshauer, M.; Schön, M.; Kosacka, J.; Fitzl, G.; Kovacs, P.; Stumvoll, M.; et al. Repin1 maybe involved in the regulation of cell size and glucose transport in adipocytes. Biochem. Biophys. Res. Commun. 2010, 400, 246-251. [CrossRef] [PubMed]

119. Takahashi, M.; Kamei, Y.; Ezaki, O. Mest/Peg1 imprinted gene enlarges adipocytes and is a marker of adipocyte size. Am. J. Physiol. Metab. 2005, 288, E117-E124. [CrossRef]

120. Yvan-Charvet, L.; Even, P.C.; Bloch-Faure, M.; Guerre-Millo, M.; Moustaid-Moussa, N.; Ferré, P.; Quignard-Boulange, A. Deletion of the Angiotensin Type 2 Receptor (AT2R) Reduces Adipose Cell Size and Protects from Diet-Induced Obesity and Insulin Resistance. Diabetes 2005, 54, 991-999. [CrossRef]

Publisher's Note: MDPI stays neutral with regard to jurisdictional claims in published maps and institutional affiliations.

(C) 2020 by the authors. Licensee MDPI, Basel, Switzerland. This article is an open access article distributed under the terms and conditions of the Creative Commons Attribution (CC BY) license (http://creativecommons.org/licenses/by/4.0/). 